\title{
Measurement of $\mathrm{Cl}^{-}: \mathrm{Br}^{-}$Ratios in the Porewater of Clay-Rich Rocks-A Comparison of the Crush-and-Leach and the Paper-Absorption Methods
}

\author{
Magda Celejewski $\mathbb{D}^{1,2}$ David Barton, ${ }^{2}$ and Tom $\mathrm{Al} \mathbb{D}^{2}$ \\ ${ }^{1}$ Department of Earth Sciences, University of New Brunswick, 2 Bailey Dr., Fredericton, NB, Canada E3B 5A3 \\ ${ }^{2}$ Department of Earth and Environmental Sciences, University of Ottawa, 25 Templeton St., Ottawa, ON, Canada K1N 6N5 \\ Correspondence should be addressed to Magda Celejewski; m.celejewski@unb.ca and Tom Al; tom.al@uottawa.ca
}

Received 17 June 2017; Revised 6 November 2017; Accepted 25 December 2017; Published 22 April 2018

Academic Editor: Jean-Michel Matray

Copyright ( $) 2018$ Magda Celejewski et al. This is an open access article distributed under the Creative Commons Attribution License, which permits unrestricted use, distribution, and reproduction in any medium, provided the original work is properly cited.

\begin{abstract}
Characterization of porewater chemistry in low-permeability, clay-rich rocks provides insights into solute transport mechanisms and the origin and residence time of porewater. Extraction of porewater for chemical quantification is challenging, and several methods have been applied including squeezing, advective displacement, crush and leach, and a relatively new technique that extracts porewater by absorption into a cellulosic paper by capillary action. Here we compare porewater $\mathrm{Cl}^{-}$and $\mathrm{Br}^{-}$mass ratios from samples using the paper-absorption and crush-and-leach techniques. Samples were obtained from Upper Ordovician shales in the Michigan Basin in Ontario, the Opalinus Clay at the Mont Terri Rock Laboratory in Switzerland, and the Upper Ordovician Lorraine Group shale in southern Quebec. The data display consistent and reproducible differences among methods for $\mathrm{Cl}^{-}$and $\mathrm{Br}^{-}$mass ratios, with the paper-absorption method producing systematically lower $\mathrm{Cl}^{-}: \mathrm{Br}^{-}$ratios. The observed differences in $\mathrm{Cl}^{-}: \mathrm{Br}^{-}$ratios are attributed primarily to anion exclusion effects which are stronger for $\mathrm{Br}^{-}$than for $\mathrm{Cl}^{-}$, resulting in higher $\mathrm{Br}^{-}$ concentrations in the largest pores that are preferentially sampled by the paper-absorption technique. In addition, calculations suggest that $\mathrm{Cl}^{-}$is more effective than $\mathrm{Br}^{-}$in forming ion pairs and clusters with neutral or positive charge which can enter the diffuse double layer. This causes a further decrease in the $\mathrm{Cl}^{-}: \mathrm{Br}^{-}$ratios for the mobile water. One important message from this work is that different extraction methods should not be expected to converge on a unique porewater $\mathrm{Cl}^{-}: \mathrm{Br}^{-}$ratio because each method reflects different proportions of the interlayer, diffuse double layer, and mobile fractions of porewater.
\end{abstract}

\section{Introduction}

The requirement for long-term geological sequestration of $\mathrm{CO}_{2}[1,2]$ and nuclear waste management [3-5] has prompted increased interest in low-permeability, clay-rich sedimentary rocks [6-12]. These rocks are characterized by low hydraulic conductivity $\left(<10^{-11} \mathrm{~m} / \mathrm{s}\right)$ and, as a consequence, solute transport is dominated by diffusion [4, 13-17]. Characterization of natural tracers, such as $\mathrm{Cl}^{-}$and $\mathrm{Br}^{-}$in the porewaters of low-permeability rocks is critical in establishing the provenance of salinity, whether marine or otherwise, as well as solute transport mechanisms and residence times $[8,10,18-23]$. Mazurek et al. [10] compiled measurements of natural conservative tracers $\left(\mathrm{Cl}^{-}\right.$and stable water isotopes) in the Opalinus Clay at Mont Terri, Switzerland, the Boom Clay at Essen, Belgium, and the Couche Silteuse at Marcoule, France, by plotting spatial profiles of tracers across these formations. The data allowed for determination of transport processes and porewater residence times.

Sampling porewater from low-permeability, clay-rich formations for chemical quantification is a challenging endeavor. This is in part due to the small volumes available for extraction and because of the complexity of waterclay interactions [24]. Negatively charged clay surfaces are balanced by cation-rich water in direct contact with the surface $[25,26]$. This cation-rich water is "bound water" and occupies the interlayer positions in clay minerals or the diffuse double layer (DDL) that surrounds mineral surfaces, 

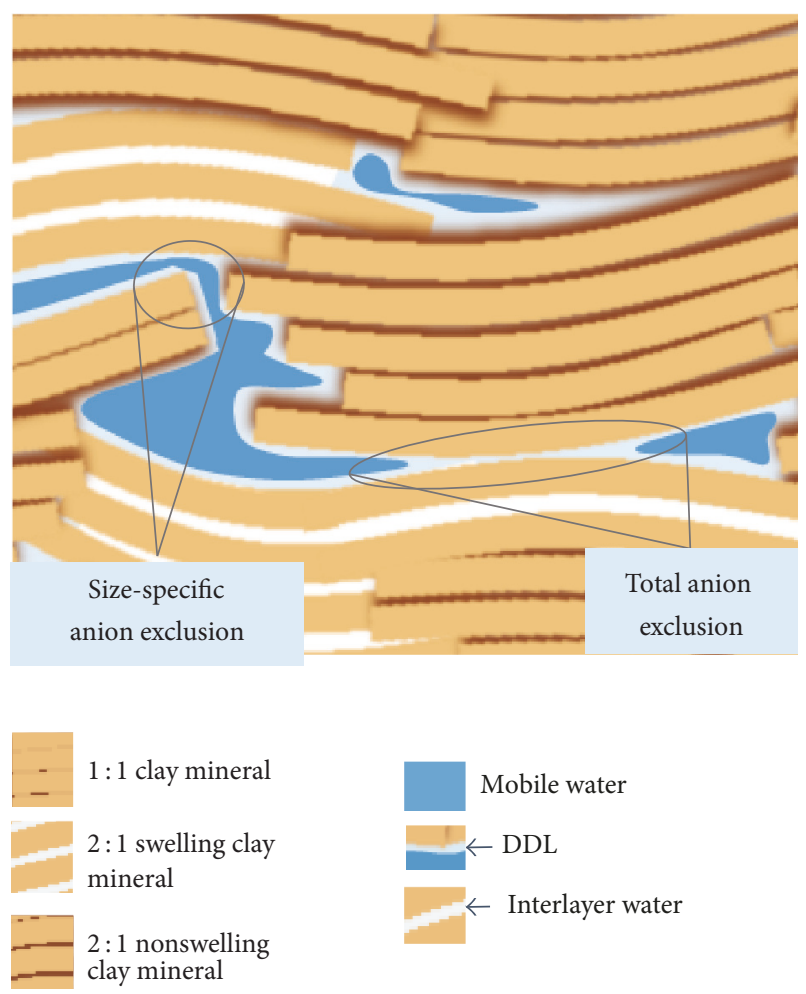

Mobile water

DDL

Interlayer water

FIgURE 1: Pore-scale conceptual model for clay-rich sedimentary rock. A variety of clay minerals are depicted, including 1:1 clay minerals, such as kaolinite, $2: 1$ nonswelling clay minerals, such as illite, and 2:1 swelling clay minerals such as smectite. The negatively charged surfaces of these minerals are balanced with cation-rich water in the DDL and in the interlayer positions of the swelling clay minerals. Mobile water is found in the larger pore spaces.

extending outward into the pore spaces [27, 28]. "Mobile water" containing a balance of cations and anions occurs outside of the DDL in larger pore spaces. Together the bound water and mobile water constitute porewater. Figure 1 presents a pore-scale conceptual model for porewater in clay-rich rocks, illustrating the three principal water types: interlayer water, DDL water, and mobile water. Considering this conceptual model, it is evident that it is not appropriate to speak of a single porewater composition, and methods developed to measure the composition of porewater should be expected to provide different results if they do not sample equal fractions of these three water types.

Porewater chemistry and solute transport are generally considered in conjunction with porosity and pore geometry, because common methods for determining aqueous solute concentrations require independent measures of solute mass and pore volume. Pearson [39] defines the porosity of a "mudrock" in terms of total physical volume (physical porosity), transport-accessible volume (transport porosity), and the volume available for geochemical reactions (geochemical porosity). Transport porosity may be further divided into porosity that is accessible to either advection or diffusion; advection porosity being limited to relatively large interconnected spaces through which porewater can flow, while diffusion porosity includes connected and dead-end pores as well as interlayer volumes. Transport and geochemical porosities define the pore space accessible to specific solutes (solute-accessible porosity) and can be dependent on measurement techniques [40]. The geometry of the pores can influence the movement of solutes due to variations in the constrictivity, connectivity, and tortuosity of the pore channels [41]. In materials with narrow pore throats, DDLs can overlap, impeding the movement of anions to cause anion exclusion effects [42]. Size-specific anion exclusion is also possible whereby DDLs are close to overlapping resulting in channels that are passable only for the relatively small anionic species.

There are several established methods to extract porewater from low-permeability rocks for chemical characterization. In some cases it is possible to directly sample porewater by collecting seepage, and this is thought to yield samples that are most representative of the mobile water fraction $[29,50]$, but the sampling durations are very long, on the order of months to years [51]. Indirect methods are also available, including out-diffusion [52-54], ultracentrifugation [55], high-pressure squeezing [48, 56, 57], crushing and leaching [48, 58-60], advective displacement [9], and absorption by paper [61]. These methods are susceptible to artefacts from disturbance of the equilibrium between minerals, bound water, and mobile water [62] that result in mineral dissolution [57], cation exchange [63], and changes in DDL thickness [64]. These artefacts may cause inconsistency among methods, particularly for the reactive cation species $[62,65]$. In addition, effects of anion exclusion [11] are manifested to varying degrees for the different extraction methods. It is common to apply corrections to account for anion exclusion artefacts in order to obtain concentrations reflective of the in situ mobile water $[10,48,66]$.

The objectives of this work are as follows: (1) to emphasize the point that the indirect methods should not be expected to provide identical results because they do not sample equal fractions of the interlayer, DDL, and mobile waters and (2) to present evidence that demonstrates differences in ionspecific porosity for the nonreactive species $\mathrm{Cl}^{-}$and $\mathrm{Br}^{-}$. A comparison approach is required to address objective 1 , but a comparison among methods that provide compositional data reflecting unknown fractions of the interlayer, DDL, and mobile waters is not valuable. With this in mind, we chose to compare $\mathrm{Cl}^{-}$and $\mathrm{Br}^{-}$mass ratios obtained from core samples using the paper-absorption method and the crushand-leach method. Crush and leach is used as a benchmark for comparison because it is expected to provide the closest possible approximation to the entire $\mathrm{Cl}^{-}$and $\mathrm{Br}^{-}$budget in all porewater $[48,58-60]$. The paper-absorption method is included in the comparison because it targets only the mobile water fraction.

\section{Materials and Methods}

2.1. Sample Collection. Clay-rich rock cores were obtained from three locations: Upper Ordovician shale from the Michigan Basin near Tiverton Ontario, Canada; Upper Ordovician Lorraine Group shale from the Appalachian 
TABLE 1: Mineralogical and Physical properties.

\begin{tabular}{|c|c|c|c|c|c|c|c|}
\hline & \multicolumn{3}{|c|}{ Michigan Basin } & \multicolumn{3}{|c|}{ Opalinus Clay } & \multirow{2}{*}{ Lorraine Group } \\
\hline & Queenstown & Georgian Bay & Blue Mountain & Sandy facies & Carbonate sandy facies & Shaly facies & \\
\hline & \multicolumn{7}{|c|}{ Mineral composition (wt.\%) $)^{\mathrm{a}, \mathrm{b}, \mathrm{c}}$} \\
\hline Calcite & $8-57$ & $3-31$ & $4-11$ & $4-22$ & $21-59$ & $12-36$ & 8 \\
\hline Dolomite & $9-3$ & $2-41$ & $2-8$ & $0-6$ & $0-1$ & $0-1$ & 7 \\
\hline Quartz & $4-17$ & $12-46$ & $30-47$ & $13-45$ & $5-29$ & $13-26$ & 27 \\
\hline Clay & $17-60$ & $23-70$ & $27-31$ & $25-66$ & $8-48$ & $36-60$ & 46 \\
\hline \multirow[t]{2}{*}{ Feldspar } & - & $2-6$ & - & $2-5$ & 3 & $1-2$ & 10 \\
\hline & \multicolumn{7}{|c|}{ Number of core samples } \\
\hline Paper absorption & 3 & 1 & 2 & 4 & - & 2 & 4 \\
\hline \multirow[t]{7}{*}{ Crush and leach } & 3 & 1 & 2 & 7 & 1 & 8 & 4 \\
\hline & \multicolumn{7}{|c|}{ Hydraulic conductivity $(\mathrm{m} / \mathrm{s})^{\mathrm{d}, \mathrm{e}}$} \\
\hline & \multicolumn{3}{|c|}{$1.1 \times 10^{-14}-1.0 \times 10^{-13}$} & \multicolumn{3}{|c|}{$2.0 \times 10^{-14}-6.0 \times 10^{-13}$} & N/A \\
\hline & \multicolumn{7}{|c|}{ Porosity (accessible loss $\%)^{\mathrm{f}, \mathrm{c}}$} \\
\hline & \multicolumn{3}{|c|}{$6-7$} & \multicolumn{3}{|c|}{$12-15$} & N/A \\
\hline & \multicolumn{7}{|c|}{ Ionic strength $(\mathrm{mol} / \mathrm{L})^{\mathrm{g}, \mathrm{h}}$} \\
\hline & & 8.2 & & & 0.4 & & N/A \\
\hline
\end{tabular}

${ }^{\mathrm{a}}[43] ;{ }^{\mathrm{b}}[44,45] ;{ }^{\mathrm{c}}$ Clark, Matray, and Waber: BDB-1 borehole investigation, unpublished; ${ }^{\mathrm{d}}[37] ;{ }^{\mathrm{e}}[46] ;{ }^{\mathrm{f}}[47] ;{ }^{\mathrm{g}}[30] ;{ }^{\mathrm{h}}[48,49] ;$ N/A = not available.

Basin at St. Édouard Quebec, Canada; and the Opalinus Clay from the Mont Terri Rock Laboratory, Switzerland. The Michigan Basin borehole (DGR8) was drilled with salt water to a depth of 724 meters below ground surface (mBGS) [67]. Rock core samples $(76 \mathrm{~mm}$ in diameter and $150-200 \mathrm{~mm}$ in length) were collected for porewater geochemical analysis from 463 to $635 \mathrm{mBGS}$. The Opalinus Clay borehole (BDB1) was drilled, using air as a flushing medium, from a tunnel in the Mont Terri Rock Laboratory in two parts to a total depth of $247 \mathrm{~m}$, with $101 \mathrm{~mm}$ diameter core recovered from 0 to $97 \mathrm{~m}$ (Hauptrogenstein and Passwang formations) and $85 \mathrm{~mm}$ diameter core recovered from 97 to $247 \mathrm{~m}$ through the Opalinus Clay and the Staffelegg Formation. Porewater geochemistry was measured on cores between 115 and $221 \mathrm{~m}$ depth. A continuous slice with a maximum thickness of $10 \mathrm{~mm}$ was removed from the periphery of the core over the length of the borehole for petrophysical, geochemical, rock mechanical, and stratigraphic studies [68]. Lorraine Group shale samples were recovered from four boreholes (F-7, F8, F-20, and F-21) drilled with freshwater, to total depths of 50 to $150 \mathrm{mBGS}$. Samples of $63.5 \mathrm{~mm}$ diameter and $300 \mathrm{~mm}$ in length were obtained from depths of 42 to $135 \mathrm{mBGS}$. All boreholes were drilled perpendicular to bedding.

Michigan Basin cores were preserved by wrapping in plastic film, then vacuum sealing, first in a nitrogen-flushed plastic bag, and then in an aluminum-lined plastic bag. Some Opalinus Clay cores were preserved by wrapping in plastic film, then vacuum sealing in an aluminum-lined plastic bag, others by vacuum sealing, first in a plastic bag, and then in an aluminum-lined plastic bag. Sample collection and preservation were completed within 30 minutes of core retrieval from the boreholes. Preserved cores were shipped in coolers with ice packs to the laboratory, where they were stored in a refrigerator at $4^{\circ} \mathrm{C}$. Core from St. Édouard had been archived by enclosing in plastic wrap and zip-lock plastic bags and then freezing. They were stored at room temperature for 6 months prior to porewater extraction.

A total of seven core samples spanning the Queenston, Georgian Bay, and Blue Mountain formations were collected from the Michigan Basin. Porewater extraction was performed by paper absorption and crush and leach on the same core samples. For the Opalinus Clay, identical samples were not used for both paper absorption and crush and leach. The paper-absorption method was applied to six core samples located between 115 and $221 \mathrm{~m}$ along the borehole depth and 16 different core samples were collected from the same depth for crush-and-leach extraction. For the Lorraine Group, four adjacent sample pairs were collected for extraction by paper absorption and crush and leach. In all cases the cores were subsampled to provide between one and five individual extracts. Key mineralogical and physical properties of the core samples are listed in Table 1.

2.2. Paper Absorption. This method is based on that described by Celejewski et al. [61]. Cores were cleaved with a hammer and chisel into pucks with a minimum thickness of $20 \mathrm{~mm}$ to expose fresh surfaces for porewater extraction. The surfaces were quickly dabbed with a carpenter tack cloth to remove fine particulates and then a $45 \mathrm{~mm}$ diameter Whatman $\odot 1$ CHR paper was placed between the core segments. The cores were pressed tight over the papers and then enclosed in plastic wrap and secured with vinyl tape to compress the paper between the core segments. The wrapped samples were further isolated from the environment in individual zip-lock plastic bags and refrigerated at $4^{\circ} \mathrm{C}$ for 55 days. We assume that all solutes are transferred to the paper at the same rate (no fractionation over time), so the only consideration for deciding the length of the extraction period is that it must be long enough to accumulate sufficient solute mass in the paper for a high-quality 
analysis. Therefore, although capillary-pressure gradients are responsible for extracting the water from the rock pores into the paper, hydrostatic equilibrium is not required. Borhan and Rungta [69] and Wang et al. [70] conducted experiments with Whatman $\odot$ Number 1 filter paper to measure the rate of water imbibition and spreading from a point source (capillary pressure at the source is the same as atmospheric pressure). An empirical model developed by Borhan and Rungta [69] indicates that complete wetting of a $45 \mathrm{~mm}$ diameter paper occurs in 4 minutes. The much higher capillary pressure of porewater in the rock would increase the wetting time but it is likely that hydrostatic equilibrium was reached before 55 days.

Michigan Basin core samples were cleaved in a room with no humidity control, whereas Opalinus Clay and Lorraine Group shale core samples were cleaved in a humidity chamber with the relative humidity $(\mathrm{RH})$ being adjusted to $95 \%$, in equilibrium with the anticipated porewater salinity. The equilibrium vapour pressure was determined with the equilibrium geochemical code, PHREEQC [71]. Evaporation rates were quantified by monitoring the mass change of $200 \mu \mathrm{L}$ of a synthetic porewater solution with an ionic strength of $8.2 \mathrm{~mol} / \mathrm{L}$ on a $45 \mathrm{~mm}$ diameter Whatman $\odot 1$ CHR paper at $12 \%$ and $82 \%$ RH (VWR model 61161-382 humidity and temperature meter).

After 55 days, the papers were removed from between the core segments and porewater solutes were leached from the papers for $24 \mathrm{hrs}$ in $15 \mathrm{~mL}$ of Type-I deionized water $\left(>18.2 \mathrm{M} \Omega \cdot \mathrm{cm}\right.$ ). Leachates were acidified to $1 \% \mathrm{HNO}_{3}$ (trace metal grade, $70 \% \mathrm{HNO}_{3}$, SCP Science). Concentrations of $\mathrm{Cl}^{-}$and $\mathrm{Br}^{-}$in the leachates were determined by ICPMS (Agilent 8800). Instrumental precision was determined from replicate analyses of matrix matched standards (SCP Science) and relative standard deviations (RSD) were less than 3\%. Instrumental accuracy was monitored by inclusion of a certified seawater standard (High Purity Standards) and all results were within $4 \%$ of accepted values.

2.3. Crush and Leach. The outer 10 to $20 \mathrm{~mm}$ of each core sample was removed with a hammer and chisel and discarded. For the Opalinus Clay and Michigan Basin samples, rock material was crushed and sieved to a 2 to $4 \mathrm{~mm}$ size range. Lorraine Group shale samples were crushed to a powder $(<100 \mu \mathrm{m}$ diameter) with a ball mill. Approximately $10 \mathrm{~g}$ (Michigan Basin and Opalinus Clay) and $5 \mathrm{~g}$ (Lorraine Group) of the crushed rock material were leached for 24 hours, in $40 \mathrm{~mL}$ (Michigan Basin and Opalinus Clay) and $20 \mathrm{~mL}$ (Lorraine Group) of Type-I deionized water for a solid/liquid mass ratio of 0.25 . Phase separation was conducted by centrifugation followed by filtration $(0.45 \mu \mathrm{m})$. The concentration of $\mathrm{Cl}^{-}$and $\mathrm{Br}^{-}$in the leachates were analyzed by ICP-MS.

The grain-size range used for samples from the Michigan Basin and the Opalinus Clay was not consistent with that used for the Lorraine Group shale, so a separate experiment to determine the effect of grain size was conducted. Two Opalinus Clay samples from the BDB-1 borehole were selected, one from a clay-rich zone and a second from a carbonate-rich zone. Core samples, $200 \mathrm{~mm}$ long, from borehole depths of $166 \mathrm{~m}$ and $189 \mathrm{~m}$, with $58 \%$ and $8 \%$ total clay content, respectively, were sawed along the length of the core into three segments, providing triplicate samples with consistent mineralogy. Each segment was coarsely crushed $(<30 \mathrm{~mm})$, homogenized, and divided into nine subsamples. Each subsample was crushed with a mortar and pestle and sieved to obtain one of nine grain-size fractions $(<37,37-75$, 75-125, 125-250, 250-500, 500-1000, 1000-2000, 2000-4000, and $4000-10000 \mu \mathrm{m})$. Approximately $10 \mathrm{~g}$ of each size fraction was leached in $40 \mathrm{~mL}$ of Type-I deionized water for a solid/liquid mass ratio of 0.25 for 24 hours. Phase separation was conducted by centrifugation followed by filtration $(0.45 \mu \mathrm{m})$. Concentration of $\mathrm{Cl}^{-}$and $\mathrm{Br}^{-}$in the leachates was quantified by ICP-MS.

\section{Results and Discussion}

The paper-absorption method removes only a few tens of milligrams of porewater from the interconnected pore spaces in direct contact with the absorbing paper. The crush-andleach method, as applied in this study, "samples" hundreds of milligrams of porewater from 5 to $10 \mathrm{~g}$ (approximately 2000 to $4000 \mathrm{~mm}^{3}$ ) of rock. Consequently, the masses of $\mathrm{Cl}^{-}$and $\mathrm{Br}^{-}$ extracted by the paper-absorption method are much smaller than those extracted by crush and leach (Table 2). To facilitate comparison of the data, scaling factors were applied to the masses extracted by crush and leach in order to fit data from both methods on a single set of axes (Figure 2). The solute masses obtained by crush and leach were divided by a factor of 10 for the Michigan Basin, 20 for the Opalinus Clay, and 3.5 for the Lorraine Group shales.

The mass ratios demonstrate consistent linear trends (Figure 2), but compared to crush and leach, the $\mathrm{Cl}^{-}: \mathrm{Br}^{-}$ ratios from the paper-absorption method are consistently lower by factors of $50 \%$ for the Lorraine Group shale, $48 \%$ for the Michigan Basin, and 25\% for the Opalinus Clay.

For the crush-and-leach method, the grain size of samples from the Michigan Basin and the Opalinus Clay was larger than for the Lorraine Group shales. Experiments conducted to investigate the effect of particle grain size for two samples of differing clay content ( $58 \%$ and $8 \%$ ) demonstrate that the $\mathrm{Cl}^{-}: \mathrm{Br}^{-}$ratios are consistent regardless of clay content and grain-size fraction for a single solid/liquid ratio $(0.25)$ and extraction duration (24 hours, Figure 3 ).

The possibility was considered that the differences in $\mathrm{Cl}^{-}: \mathrm{Br}^{-}$ratios are artefacts from mineral precipitation and/or dissolution. Halite is present in the Michigan Basin core samples [6], and, as a consequence, the $\mathrm{Cl}^{-}$ion is not entirely conservative in this system. Dissolution of preexisting halite during the leaching step would be expected to cause an increase in the $\mathrm{Cl}^{-}: \mathrm{Br}^{-}$ratio relative to that in the mobile water. However, it is unlikely that the influence of halite dissolution would be equal for all samples and, given that there is very little scatter in the $\mathrm{Cl}^{-}: \mathrm{Br}^{-}$ratios for crush-and-leach extracts from the Michigan Basin, the influence of halite dissolution is believed to be negligible (i.e., the mass balance is dominated by $\mathrm{Cl}^{-}$in the mobile water). In processing the Michigan Basin samples for the paper-absorption method, the porewater is known to have 
TABLE 2: Masses $(\mu \mathrm{g})$ of $\mathrm{Cl}^{-}$and $\mathrm{Br}^{-}$extracted by the crush-andleach and paper-absorption methods.

\begin{tabular}{|c|c|c|c|c|c|}
\hline \multicolumn{3}{|c|}{ Crush and leach } & \multicolumn{3}{|c|}{ Paper absorption } \\
\hline Sample & $\mathrm{Cl}^{-}$ & $\mathrm{Br}^{-}$ & Sample & $\mathrm{Cl}^{-}$ & $\mathrm{Br}^{-}$ \\
\hline \multicolumn{6}{|c|}{ Michigan Basin } \\
\hline $463 a$ & 53928 & 630 & $463 a$ & 641 & 15 \\
\hline $463 b$ & 63586 & 744 & $463 b$ & 1109 & 26 \\
\hline $495 a$ & 45262 & 562 & $495 a$ & 5355 & 129 \\
\hline $495 b$ & 49897 & 584 & $495 b$ & 4434 & 112 \\
\hline 522 & 49783 & 615 & 522 & 4224 & 107 \\
\hline 531 & 20635 & 261 & 531 & 4057 & 93 \\
\hline $571 \mathrm{a}$ & 70851 & 884 & $571 \mathrm{a}$ & 5739 & 117 \\
\hline $571 b$ & 80998 & 874 & $571 b$ & 4119 & 87 \\
\hline $571 \mathrm{c}$ & 79415 & 875 & $571 c$ & 3667 & 76 \\
\hline $626 a$ & 53887 & 620 & $626 a$ & 5077 & 125 \\
\hline $626 b$ & 54301 & 659 & $626 b$ & 5718 & 131 \\
\hline $634 \mathrm{a}$ & 53411 & 615 & $634 \mathrm{a}$ & 1474 & 35 \\
\hline $634 b$ & 55397 & 635 & $634 \mathrm{~b}$ & 1420 & 33 \\
\hline $634 c$ & 54416 & 612 & $634 c$ & 1761 & 40 \\
\hline $634 \mathrm{~d}$ & 59462 & 678 & $634 d$ & 4242 & 95 \\
\hline $634 \mathrm{e}$ & 55150 & 637 & $634 \mathrm{e}$ & 3290 & 82 \\
\hline \multicolumn{6}{|c|}{ Lorraine Group Shales } \\
\hline F7-1 & 289 & 2.71 & F7-3 & 109 & 1.59 \\
\hline F7-2 & 295 & 2.75 & F7-4 & 91 & 1.32 \\
\hline F8-1 & 80 & 0.38 & F8-3 & 24 & 0.20 \\
\hline F8-2 & 78 & 0.39 & F8-4 & 16 & 0.16 \\
\hline F20-1 & 1162 & 9.87 & F20-3 & 148 & 2.5 \\
\hline F20-2 & 1209 & 10.4 & F20-4 & 287 & 5.13 \\
\hline $444-1$ & 121 & 1.66 & $444-2$ & 55 & 1.08 \\
\hline \multicolumn{6}{|c|}{ Opalinus Clay } \\
\hline 115.1 & 542 & 1.63 & 115 & 77 & 0.28 \\
\hline 115.2 & 550 & 1.73 & & & \\
\hline 115.3 & 493 & 1.51 & & & \\
\hline 115.4 & 625 & 1.92 & & & \\
\hline 119.1 & 1061 & 3.54 & & & \\
\hline 119.2 & 984 & 3.32 & & & \\
\hline 119.3 & 948 & 3.12 & & & \\
\hline 119.4 & 996 & 3.37 & & & \\
\hline 121.1 & 1163 & 3.85 & 128.1 & 85 & 0.33 \\
\hline 121.2 & 1185 & 3.85 & 128.2 & 83 & 0.34 \\
\hline 121.3 & 1239 & 4.14 & & & \\
\hline 121.4 & 1131 & 3.72 & & & \\
\hline 132.2 & 1454 & 4.74 & $144 \mathrm{a}$ & 73 & 0.30 \\
\hline 132.2 & 1554 & 4.90 & $144 \mathrm{~b}$ & 70 & 0.35 \\
\hline 132.3 & 1576 & 5.00 & & & \\
\hline 132.4 & 1467 & 4.47 & & & \\
\hline 161.1 & 2899 & 9.39 & & & \\
\hline 161.2 & 2832 & 9.00 & & & \\
\hline 161.3 & 3049 & 9.70 & & & \\
\hline 161.4 & 2539 & 8.02 & & & \\
\hline 166.2 & 3418 & 10.84 & & & \\
\hline 166.3 & 3367 & 10.73 & & & \\
\hline 166.4 & 2886 & 9.21 & & & \\
\hline 172.1 & 2469 & 7.86 & & & \\
\hline 172.2 & 2581 & 8.36 & & & \\
\hline 172.3 & 2517 & 8.11 & & & \\
\hline 172.4 & 2519 & 7.94 & & & \\
\hline 174.1 & 2702 & 8.42 & & & \\
\hline 174.2 & 2857 & 8.97 & & & \\
\hline
\end{tabular}

TABLE 2: Continued.

\begin{tabular}{|c|c|c|c|c|c|}
\hline \multicolumn{3}{|c|}{ Crush and leach } & \multicolumn{3}{|c|}{ Paper absorption } \\
\hline Sample & $\mathrm{Cl}^{-}$ & $\mathrm{Br}^{-}$ & Sample & $\mathrm{Cl}^{-}$ & $\mathrm{Br}^{-}$ \\
\hline 174.3 & 2555 & 7.82 & & & \\
\hline 174.4 & 2587 & 8.22 & & & \\
\hline 179.1 & 1684 & 5.15 & $178 \mathrm{a}$ & 185 & 0.74 \\
\hline 179.2 & 1715 & 5.37 & $178 \mathrm{~b}$ & 177 & 0.75 \\
\hline 179.3 & 1613 & 5.04 & & & \\
\hline 179.4 & 1601 & 4.96 & & & \\
\hline 190.2 & 1473 & 4.81 & & & \\
\hline 190.3 & 1467 & 4.78 & & & \\
\hline 190.4 & 1462 & 4.79 & & & \\
\hline 192.1 & 3318 & 10.62 & & & \\
\hline 192.2 & 3228 & 10.42 & & & \\
\hline 192.3 & 3065 & 10.05 & & & \\
\hline 192.4 & 3222 & 10.28 & & & \\
\hline 203.1 & 3767 & 11.98 & $204 a$ & 179 & 0.77 \\
\hline 203.2 & 3712 & 11.78 & $204 \mathrm{~b}$ & 170 & 0.70 \\
\hline 203.3 & 3768 & 12.01 & $204 c$ & 165 & 0.71 \\
\hline 203.4 & 3698 & 11.96 & $204 d$ & 163 & 0.81 \\
\hline 209.1 & 4002 & 12.82 & & & \\
\hline 209.2 & 3608 & 11.59 & & & \\
\hline 209.3 & 3351 & 10.87 & & & \\
\hline 209.4 & 3365 & 10.73 & & & \\
\hline 220.2 & 2880 & 9.05 & & & \\
\hline 220.3 & 2752 & 8.54 & & & \\
\hline 220.4 & 2751 & 8.59 & & & \\
\hline
\end{tabular}

been affected to some degree by evaporation, and this would be expected to cause precipitation of halite. The $\mathrm{Br}^{-}$ion does not easily substitute for $\mathrm{Cl}^{-}$in the halite structure [72], so evaporation, and subsequent halite precipitation, could cause fractionation of $\mathrm{Cl}^{-}$and $\mathrm{Br}^{-}$in the residual porewater, decreasing the $\mathrm{Cl}^{-}: \mathrm{Br}^{-}$ratio. There is little scatter in the data so, if evaporation is responsible for the observed difference in the ratios, the degree of evaporation must have been uniform for all samples, which seems unlikely. In addition, samples from the Opalinus Clay and the Lorraine Group shale were prepared in a humidity-controlled chamber (95\% $\mathrm{RH}$ ) and evaporation effects were eliminated (Figure 4) yet the differences in the $\mathrm{Cl}^{-}: \mathrm{Br}^{-}$ratios are also present in those datasets. For these reasons, dissolution and precipitation of halite are not considered plausible explanations for the observed differences in $\mathrm{Cl}^{-}: \mathrm{Br}^{-}$ratios.

Additional disturbances caused during preparation of the core for porewater extraction have been considered. Oxidation of pyrite during sample preparation in aerobic conditions does not affect $\mathrm{Cl}^{-}: \mathrm{Br}^{-}$ratios in porewater. A damage zone created at the surface of freshly cleaved core can promote crack formation. However, cracks should have no effect on the paper-absorption method for extracted $\mathrm{Cl}^{-}$and $\mathrm{Br}^{-}$masses, except perhaps a slight decrease in water yield.

The $\mathrm{Cl}^{-}: \mathrm{Br}^{-}$ratios for samples of seepage collected over the span of three years from approximately $6 \mathrm{~m}$ long segments of boreholes in the Mont Terri Rock Laboratory and reported by Pearson et al. [29] are presented in Figure 2. These samples represent water that has equilibrated with the formation as it seeps into the boreholes. The $\mathrm{Cl}^{-}: \mathrm{Br}^{-}$ratios of seepage waters plot between the ratios measured in porewater extracted 

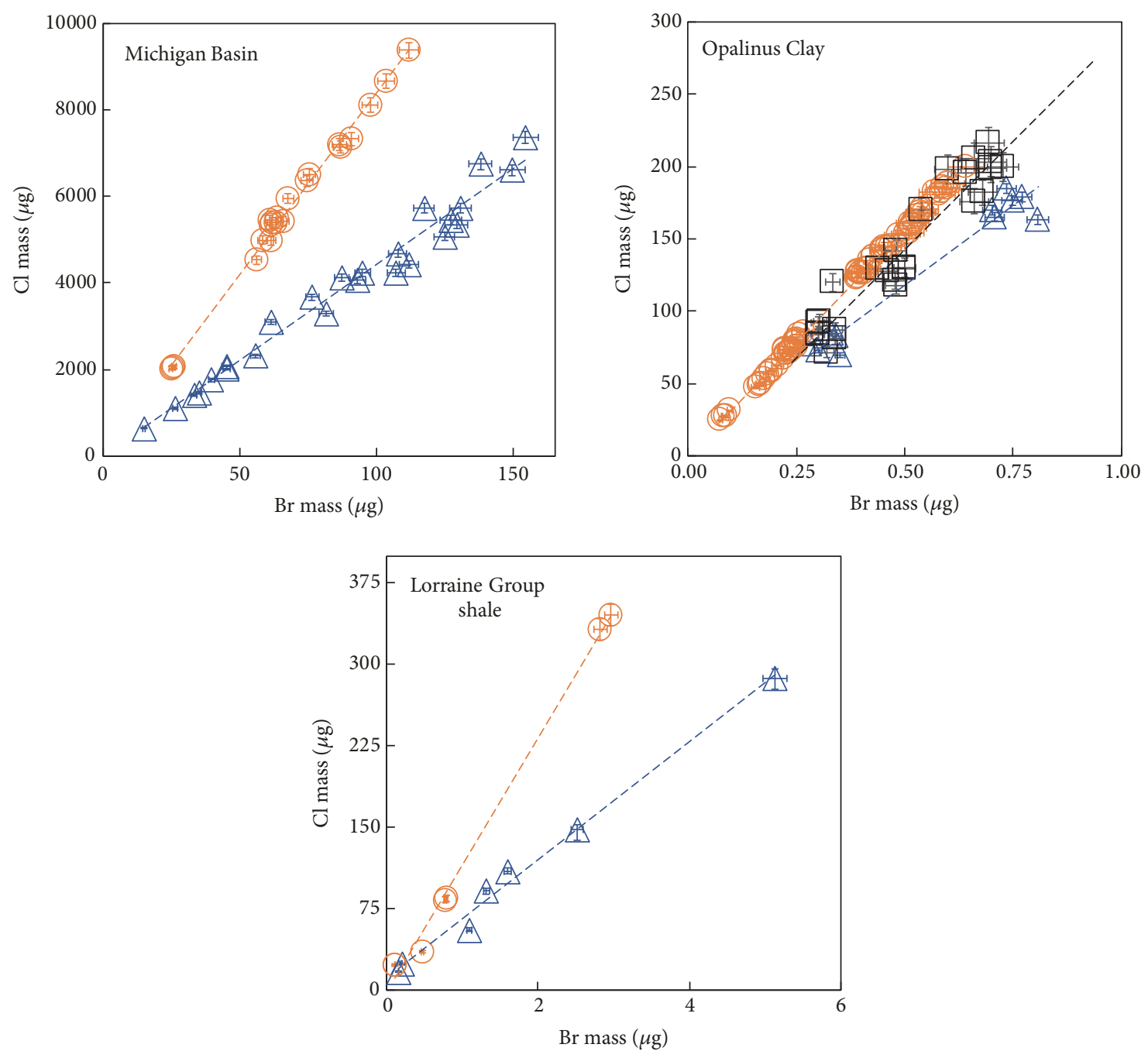

$\triangle$ Paper absorption
$\bigcirc$ Crush and leach
$\square$ Seepage

FIGURE 2: $\mathrm{Cl}^{-}$versus $\mathrm{Br}^{-}$mass extracted using the paper-absorption and crush-and-leach methods for rock cores from the Michigan Basin, Opalinus Clay, and the Lorraine Group. Scaling factors of 10, 20, and 3.5, respectively, were applied to the masses extracted by crush and leach to allow for direct comparison between methods. A scaling factor of 50 was applied to the solute masses $\left(\mathrm{L}^{-1}\right)$ in the seepage water collected from boreholes in Opalinus Clay by Pearson et al. [29]. Error bars represent the instrumental error on solute analysis.

by the crush-and-leach and paper-absorption methods. This intermediate behavior might be expected if the inflowing water is derived from mobile water but undergoes diffusive mixing with porewater in the rock matrix adjacent to flow paths. This form of fracture-matrix diffusive interaction was first reported by Foster [73].

3.1. Porewater Model. A commonly used conceptual model for porewater occurrence in low-permeability clay-rich sedimentary rock is depicted in Figure 5(a). This model consists of three types of water: mobile water, DDL water, and interlayer water. All types of water and the minerals are considered to be in chemical equilibrium. Both interlayer and DDL waters are in direct contact with negatively charged clay mineral surfaces and consequently are cation-rich. The thickness of the DDL is commonly equated to the Debye length $\left(\kappa^{-1}, \mathrm{~nm}\right)$ [see $\left.(1) ;[63,74]\right]$ :

$$
\kappa^{-1}=\frac{0.309}{\sqrt{I}},
$$

where $I$ is the ionic strength of the porewater $(\mathrm{mol} / \mathrm{L})$. Dissolved anionic species are considered to be limited, predominantly, to the mobile fraction of porewater, with lower concentrations in the DDL and absent from interlayer water.

Each porewater extraction method relies on different extraction mechanisms and, consequently, they do not sample equal portions of the different porewater fractions. For 


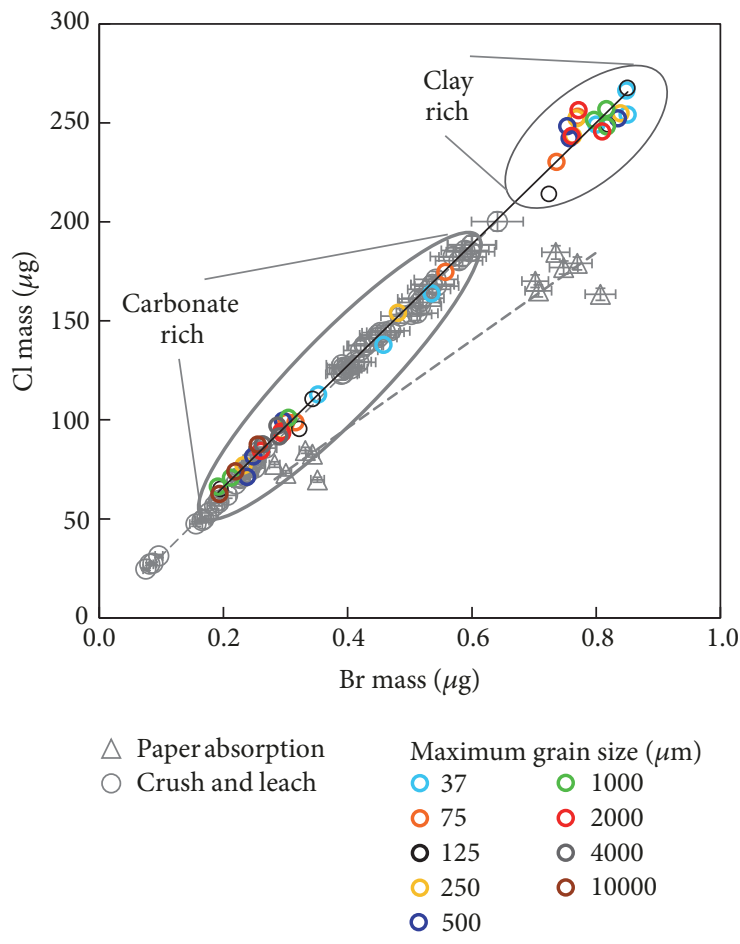

FIgURE 3: Anion masses extracted by crush and leach from Opalinus Clay samples crushed to a range of grain sizes $(<37,37-75$, $75-125,125-250,250-500,500-1000,1000-2000,2000-4000$, and $4000-10000 \mu \mathrm{m})$.

this reason, it is expected that the two methods should provide different results. The crush-and-leach method is assumed to extract all conservative anions from the porewater $[48,56,58-60]$, while the paper-absorption method relies on capillary-pressure gradients to draw water from the mobile water fraction. Hodgson and Berg [75] measured wetting angles $(\theta)$ for individual cellulose fibres and they report angles ranging from $0^{\circ}$ for receding measurements to $>14^{\circ}$ for advancing measurements. Pore-size measurements for cellulose fibres are available from Park et al. [76] and they report pore radii on the order of 9 to $10 \mathrm{~nm}$. Using a $\theta$ of $14^{\circ}$, a pore radius $(r)$ of $10 \mathrm{~nm}$ and a surface tension $(\gamma)$ for water of $0.0715 \mathrm{~N} / \mathrm{m}$ [75] to calculate the capillary pressure $\left(P_{c}\right)$ of water in the fibres with the Young-Laplace relationship,

$$
P_{c}=\frac{2 \gamma \cos \theta}{r},
$$

yield a value of $14 \mathrm{MPa}$. Intera [37] reports air-entry pressures for the shales in the Michigan Basin ranging from 9 to $29 \mathrm{MPa}$, and Marschall et al. [38] report air-entry pressures between 0.4 and $10 \mathrm{MPa}$ for the Opalinus Clay. These values indicate that the capillary pressure in the paper exceeds that for the biggest pores in the rocks and the paper is capable of pulling water from the largest interconnected pores (Figure 5(b)).

The distance over which capillary-pressure gradients are operating can be roughly estimated. For the Opalinus Clay, the paper-absorption method removed up to $26 \mathrm{mg}$ of porewater. With the following simplifying assumptions: (1)

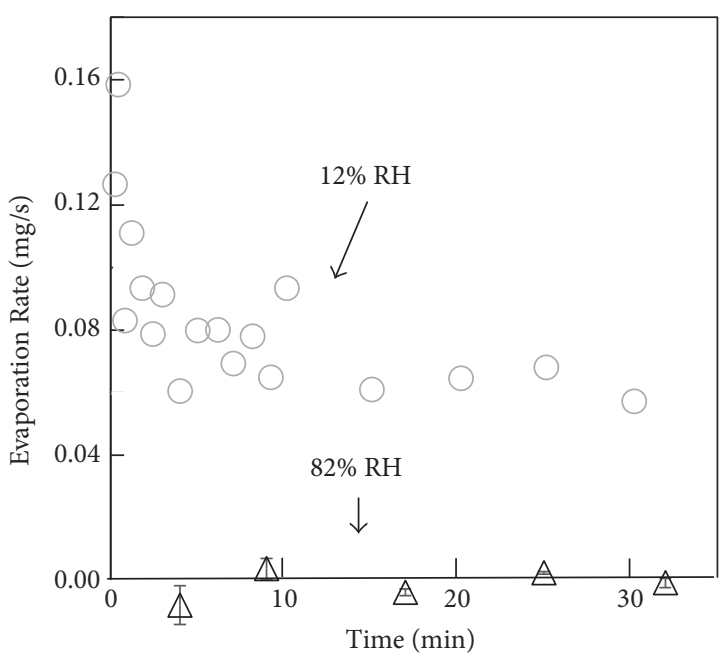

FIGURE 4: Evaporation rates of synthetic porewater [30] under open lab conditions $(12 \% \mathrm{RH})$ and in a humidity chamber $(82 \% \mathrm{RH})$.

the mobile water porosity is equal to the anion-accessible porosity, (2) the anion-accessible porosity represents $50 \%$ of the total porosity [48], (3) $50 \%$ of the anion-accessible porewater is drained from pores adjacent to the paper, and (4) a total porosity of $12 \%$ (Table 1); then the depth of porewater extraction is on the order of $300 \mu \mathrm{m}$ :

$$
\text { Depth }=\frac{V_{\mathrm{H}_{2} \mathrm{O}} /(n \cdot 0.5)}{2 \mathrm{SA}},
$$

where $V_{\mathrm{H}_{2} \mathrm{O}}$ is the volume of porewater extracted, $n$ is the anion-accessible porosity, and SA is the area of the absorbing paper.

The distribution of dissolved anions is limited, predominantly, to the mobile fraction [39, 77-80], but very little is known about the distribution of specific anions in the pore space. It is understood that anionic species are affected by anion exclusion in clay-rich media [81-83] and that not all anions are affected equally [12, 24, 84, 85]. Appelo et al. [24] conducted diffusion experiments using a suite of tracers, including ${ }^{36} \mathrm{Cl}^{-}$and $\mathrm{Br}^{-}$on a single sample of Opalinus Clay. They describe differences in diffusive behavior of $\mathrm{Cl}^{-}$and $\mathrm{Br}^{-}$ in terms of a geometric factor, $G_{f}$ [see (4); [86]]:

$$
G_{f}=\frac{\tau^{2}}{\delta}
$$

where $\tau$ is tortuosity and $\delta$ is constrictivity. Appelo et al. [24] report a geometric factor of 9.24 for $\mathrm{Cl}^{-}$and 9.54 for $\mathrm{Br}^{-}$, indicating a lower mobility for $\mathrm{Br}^{-}$than for $\mathrm{Cl}^{-}$in the Opalinus Clay. They discuss the differences in anion mobility in terms of ion pairing and the orientation and number of water molecules in the first hydration shell of the ions. They suggest that differences in $\mathrm{Na}-\mathrm{Cl}, \mathrm{Na}-\mathrm{Br}$, and Na-I association constants reported by Fuoss [87] could explain the variations they observe in geometric factors, but they note that the occurrence of alkali-halide ion pairing is generally not recognized in aqueous speciation modelling 


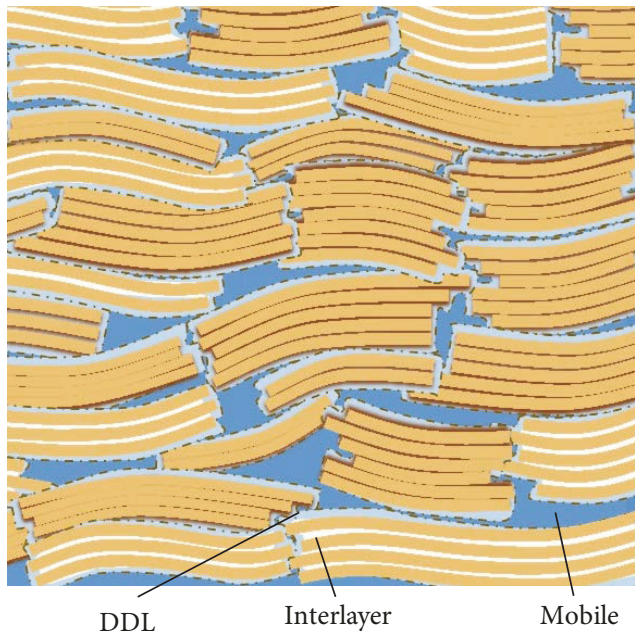

(a)

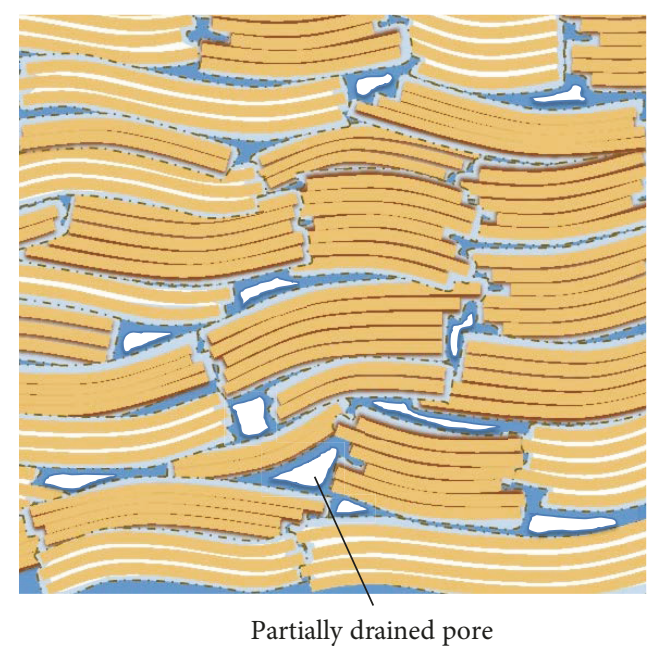

(b)

Figure 5: (a) A pore-scale conceptual model of the different porewater fractions found in a low-permeability clay-rich sedimentary rock. (b) The paper-absorption method extracts porewater from the largest interconnected pores. In this example, partially drained pore spaces are assumed to be connected in the third dimension.

(e.g., PHREEQC). The issue of orientation and number of water molecules in the first hydration shell of the ions is closely related to the effect of ion size and hydration on anion exclusion which is discussed further below. Nakata et al. [11] examined the effects of pressures and smectite content on $\mathrm{Cl}^{-}$and $\mathrm{Br}^{-}$concentrations in porewater squeezed from two mudstones: (1) the Wakkanai Formation at the Horonobe underground research laboratory, Japan with $40 \%$ smectite, and (2) the Wallumbilla Formation at Marree, South Australia, containing $11 \%$ smectite. The rocks were equilibrated with solutions of known $\mathrm{Cl}^{-}$and $\mathrm{Br}^{-}$concentrations and then squeezed to retrieve porewater for comparison to the known solutions. Concentrations of $\mathrm{Cl}^{-}$and $\mathrm{Br}^{-}$in the squeezed porewater were normalized to the equilibration solution, and at all pressure increments the concentration of $\mathrm{Cl}^{-}$was higher than $\mathrm{Br}^{-}$. The authors attributed this to extraction from closed pore spaces that were not accessible to equilibration with the external saturating solution. However, the consistent difference between $\mathrm{Cl}^{-}$and $\mathrm{Br}^{-}$concentrations at all squeezing pressures suggests that the accessible porosities for these anions differ.

The consistent and strongly contrasting results obtained from the crush-and-leach versus the paper-absorption technique provide additional evidence that $\mathrm{Cl}^{-}$and $\mathrm{Br}^{-}$behave differently in the confined pore spaces of clay-rich rocks. Physical and chemical mechanisms that can explain these observations are explored below.

3.2. Ion Pairing and Clustering. Ion pairing refers to a shortlived association between oppositely charged ions in aqueous solutions [88-90]. Ion clusters that include greater than two ions are also possible and can form neutral, positively, or negatively charged species. The extent of ion pairing and clustering between alkali metals and halides has been quantified experimentally and by molecular dynamics simulations for many combinations of atoms and molecules [32, 87, 91-94]. These studies show that several parameters are important for ion pairing and clustering, including solute concentrations (ionic strength), solute ratios, relative sizes of ions in the pairs, and temperature. The change in speciation and ion charge caused by ion pairing between alkali metals and halides can affect transport of anions through clay matrices. Soniat et al. [93] found that cations preferentially cluster, indicating that positively charged species form more readily than negatively charged species. These positively charged species will exhibit higher effective diffusion coefficients than negatively charged species because of their ability to diffuse through the DDL $[95,96]$.

Chen and Pappu [32] conducted molecular dynamics simulations to estimate the importance of ion association in alkali-halide solutions and to determine ion-association coefficients $\left(K_{\text {assoc }}\right)$ for ion pairs and clusters containing combinations of $\mathrm{Na}^{+}, \mathrm{K}^{+}, \mathrm{Cl}^{-}$, and $\mathrm{Br}^{-}$. The $K_{\text {assoc }}$ values from Chen and Pappu [32] should be considered stoichiometric equilibrium coefficients because they apply to mass-action expressions involving aqueous concentrations rather than activities. They correspond well to $K_{\text {assoc }}$ values measured previously by Fuoss [87] and were used to calculate the concentrations of free ions, neutral, positively, and negatively charged ion pairs, and clusters. These calculations were conducted by an iterative process in a spreadsheet using concentrations for various degrees of evaporated seawater with ionic strengths ranging from 0.7 to $11.3 \mathrm{~mol} / \mathrm{L}$ [31]. This is a reasonable proxy because porewaters in the Michigan Basin [97, 98] and the Opalinus Clay [29] are considered to be derived from seawater. The fractions of $\mathrm{Cl}^{-}$and $\mathrm{Br}^{-}$ occurring in the form of positively charged and neutral species are compared in Figure 6. The fraction of $\mathrm{Cl}^{-}$in positively charged and neutral species is $2 \%$ to $7 \%$ higher than for $\mathrm{Br}^{-}$, and, consistent with electrolyte theory [99], 


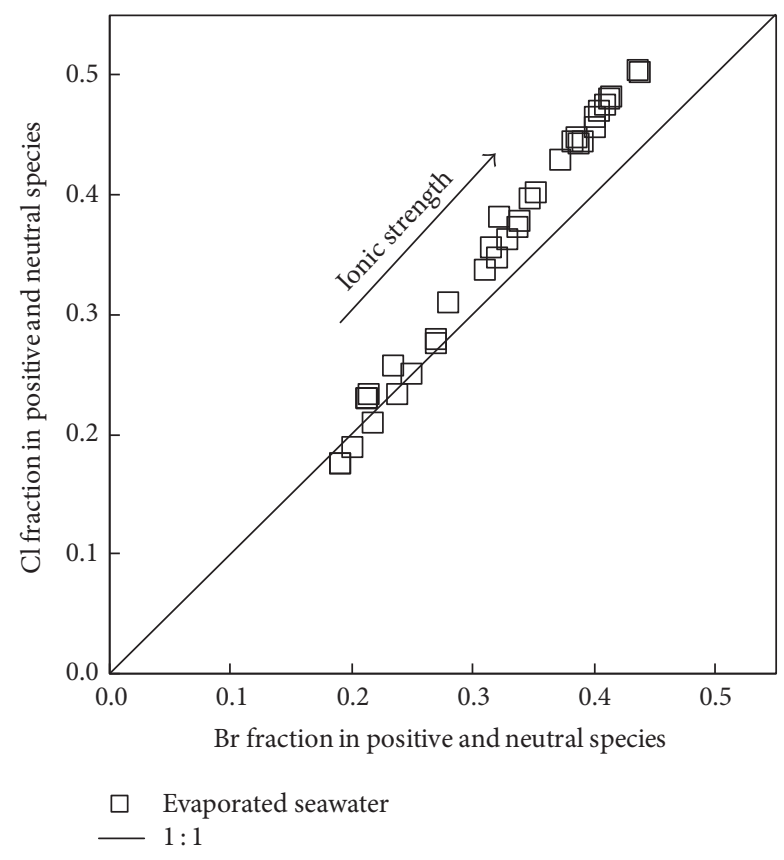

FIGURE 6: Fraction of $\mathrm{Cl}^{-}$and $\mathrm{Br}^{-}$occurring in the form of positively charged and neutral ion pairs and clusters. Calculations are for seawater, evaporated to variable degrees [31], using $K_{\text {assoc }}$ values from Chen and Pappu [32].

the extent of ion pairing and clustering increases with ionic strength. In the pore space of clay-rich sedimentary rocks, this would mean that $\mathrm{Cl}^{-}$would have a greater tendency to enter the DDL, and perhaps even the interlayer pore spaces, thereby decreasing the $\mathrm{Cl}^{-}: \mathrm{Br}^{-}$ratio in the mobile water. This is consistent with the observed difference in $\mathrm{Cl}^{-}: \mathrm{Br}^{-}$ ratios obtained from the crush-and-leach versus the paperabsorption techniques and suggests that ion pairing behavior could be a contributing factor.

3.3. Anion Specific Porosity. Solute extraction methods such as out-diffusion and crush-and-leach depend on measures of the diffusion-accessible porosity to report solute concentrations, and ion-specific diffusion-accessible porosities are required for cations and anions. The diffusion-accessible porosity for anions in the Opalinus Clay is thought to be approximately $50 \%$ of the total diffusion-accessible porosity $[10,19,24,56]$. There is an excess of cations over anions in interlayer water and the DDL in clay-rich rocks, and, as a consequence, cation-accessible porosity is greater than anion-accessible porosity [24,39].

Based on physical principles it can be expected that size-specific anion exclusion (Figure 1) will occur in highly compacted, clay-rich rocks [100]. Size-specific anion exclusion should result in fractionation of anions of differing size/charge and a nonuniform anionic distribution in the pore spaces. Hydrated anion radii are compared in Figure 7, demonstrating that there is a systematic increase in radii with increasing atomic number among the halides. Based on (1) and synthetic porewater compositions (Table 1), an estimated

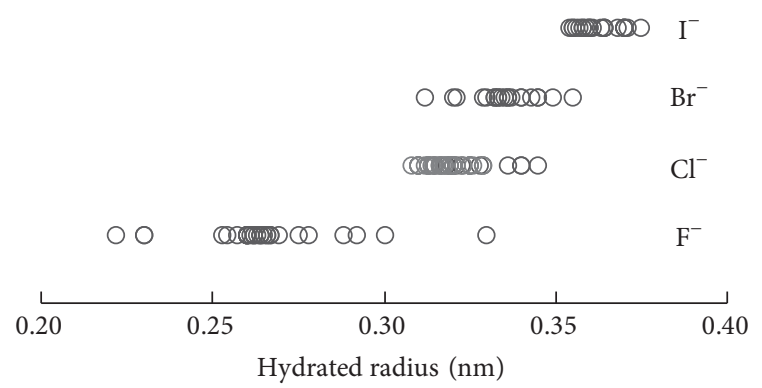

FIGURE 7: Compilation of hydrated anion radii reported in the literature $[33,34]$.

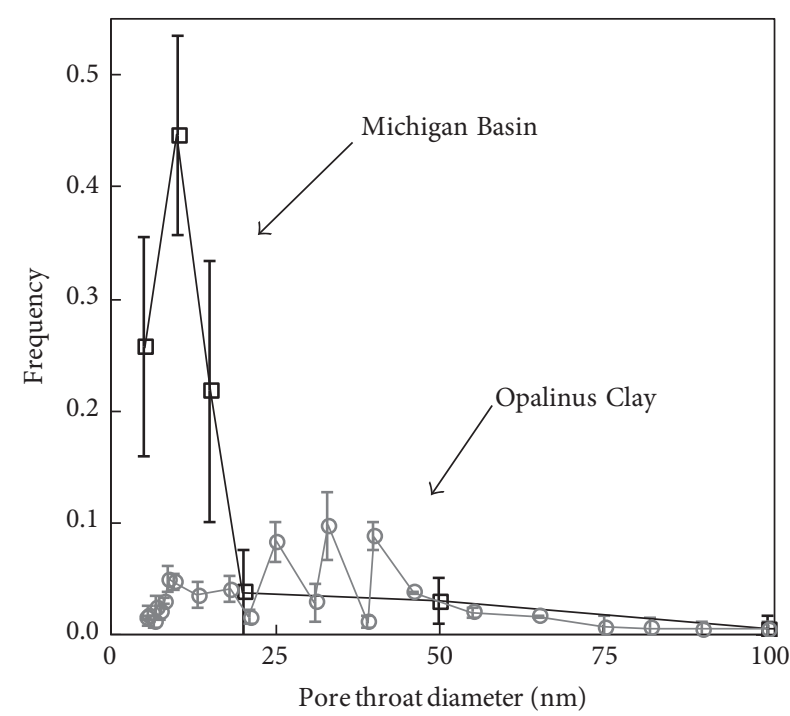

FIgure 8: Pore throat diameters quantified by MIP. Opalinus clay data (adapted from [35]) from a pair of samples from the Mont Terri Rock Laboratory (borehole BCS-2, gallery 98). Data for the Michigan Basin (adapted from [36]) are from the Queenston, Georgian Bay, and Blue Mountain formation shales. The error bars represent standard deviation.

DDL thickness in the Michigan Basin rocks and Opalinus Clay should be on the order of 0.1 and $0.5 \mathrm{~nm}$, respectively. It follows that the $5.6 \%$ difference in hydrated-ion radii for $\mathrm{Br}^{-}$ versus $\mathrm{Cl}^{-}$could lead to fractionation of these anions in pore spaces with connecting pore throat dimensions on the order of 1 to $2 \mathrm{~nm}$. In effect, this would result in a system within which the accessible porosity for $\mathrm{Cl}^{-}$is greater than for $\mathrm{Br}^{-}$.

There is no information available for pore throat diameters in the Lorraine Group shale, but mercury intrusion porosimetry (MIP) data are available from the Michigan Basin rocks and the Opalinus Clay (Figure 8). It is recognized that clay-rich rocks have pores that are inaccessible to MIP measurement, but here we assume that differences among samples will be proportional at the smallest, inaccessible pore sizes. Median pore throat diameters for the Opalinus Clay range from 20-30 nm [35] and values on the order of $9 \mathrm{~nm}$ are reported for shales from the Michigan Basin [36]. The ionicstrength effect on the respective DDL thicknesses is small 

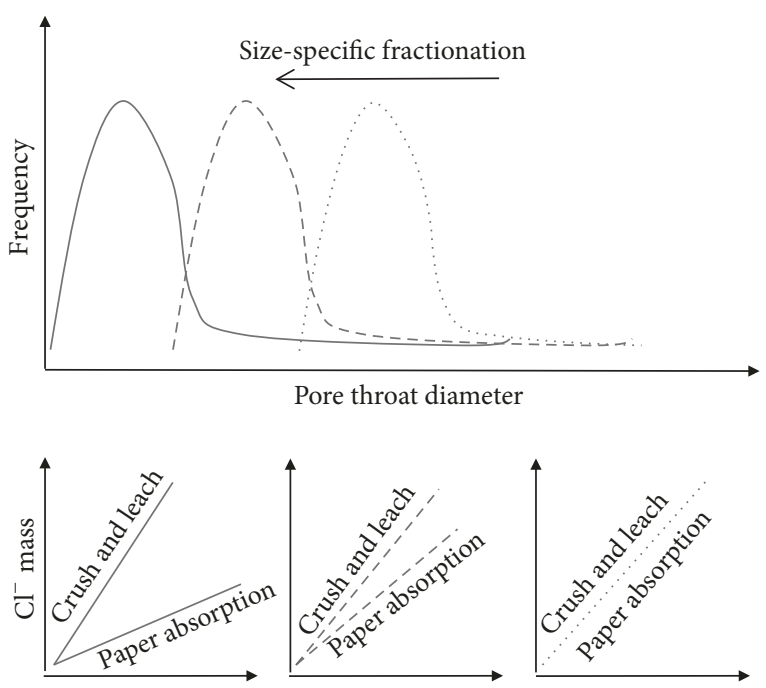

$\mathrm{Br}^{-}$mass

FIGURE 9: Conceptual model depicting the fractionation of $\mathrm{Br}^{-}$from $\mathrm{Cl}^{-}$due to size-specific anion exclusion and the relationship to pore throat diameter.

in comparison, varying from $0.1 \mathrm{~nm}$ for the Michigan Basin, to $0.5 \mathrm{~nm}$ for the Opalinus Clay [see (1)]. Size-specific anion exclusion should, therefore, be more effective in the Michigan Basin rocks. This inference is consistent with the greater fractionation of $\mathrm{Br}^{-}$from $\mathrm{Cl}^{-}$observed for the Michigan Basin rocks compared to the Opalinus Clay. The Lorraine Group shales are also highly indurated rocks, even more so than the shales from the Michigan Basin, so it is expected that the median pore throat diameter would be similar to the rocks from the Michigan Basin. A conceptual model for the effect of pore throat diameter on $\mathrm{Cl}^{-}: \mathrm{Br}^{-}$ratios extracted using the crush-and-leach and the paper-absorption methods is presented in Figure 9.

Given that capillary pressure is inversely proportional to pore diameter, the paper-absorption method will selectively extract porewater from the largest pores where $\mathrm{Cl}^{-}: \mathrm{Br}^{-}$ratios are lowest due to size-specific anion exclusion. This inference is consistent with the experimental data. Crush-and-leach extraction, on the other hand, is not selective on the basis of pore size and connectivity, and it extracts virtually all porewater solutes, resulting in higher $\mathrm{Cl}^{-}: \mathrm{Br}^{-}$ratios.

This study used Whatman $\odot 1$ CHR paper, but there will be some variability in the physical properties of different paper products. It is possible that anion ratios measured with the paper-absorption method may be somewhat specific to the choice of paper, but this remains to be tested.

If the model presented in Figure 9 is correct, then the air-entry pressures for the rocks should correlate to the difference in $\mathrm{Cl}^{-}: \mathrm{Br}^{-}$ratios measured by the two methods. Expressed as a percent, the differences $\left(\Delta \mathrm{Cl}^{-}: \mathrm{Br}^{-}\right)$are $48 \%$ for the Michigan Basin, 50\% for the Lorraine Group, and $25 \%$ for the Opalinus Clay. The are no air-entry data available for the Lorraine Group, but the air-entry data from the Michigan Basin and the Opalinus Clay have been plotted versus $\Delta \mathrm{Cl}^{-}: \mathrm{Br}^{-}$in Figure 10. There are only two points so it

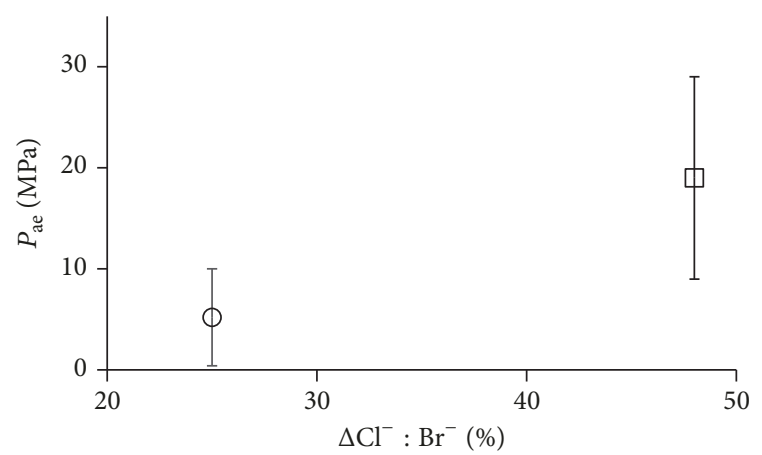

FIGURE 10: Relationship between air-entry pressure $\left(P_{\mathrm{ae}}\right)$ and the difference in $\mathrm{Cl}^{-}: \mathrm{Br}^{-}$ratios $\left(\Delta \mathrm{Cl}^{-}: \mathrm{Br}^{-}\right)$measured by the crushand-leach versus the paper-absorption method for the Opalinus Clay (circles) and the Michigan Basin (squares). The error bars represent the range of air-entry pressures reported by Intera [37] for Ordovician shales in the Michigan Basin and by Marschall et al. [38] for the Opalinus Clay.

remains for future work to determine the strength and nature of such a relationship.

\section{Conclusions}

The mass ratios for $\mathrm{Cl}^{-}$and $\mathrm{Br}^{-}$extracted from lowpermeability shales differ according to the method of extraction employed. It is generally accepted that the crush-andleach technique extracts the entire budget of conservative anions from a rock sample, so the $\mathrm{Cl}^{-}: \mathrm{Br}^{-}$ratio obtained by this method can be considered a benchmark representing the overall mass ratio. The $\mathrm{Cl}^{-}: \mathrm{Br}^{-}$ratio was found to be independent of the grain size used (between 37 and $10000 \mu \mathrm{m}$ ) for crush-and-leach extraction. The paper-absorption technique relies on capillary-pressure gradients and therefore extracts water from the largest, connected pores. Results from this method should reflect the mobile water with minimal influence from water contained in the DDL and in clay interlayers. The $\mathrm{Cl}^{-}: \mathrm{Br}^{-}$ratios obtained from the paperabsorption method (mobile water) are consistently lower than those from crush-and-leach method, indicating that $\mathrm{Cl}^{-}$ and $\mathrm{Br}^{-}$are not uniformly distributed in the mobile water, nor are they uniformly excluded from the interlayer and DDL water. The data indicate that $\mathrm{Br}^{-}$is fractionated preferentially into the largest pores that are accessible by the paperabsorption method. This fractionation can be explained by two mechanisms. First, size-specific anion exclusion causes the slightly larger $\mathrm{Br}^{-}$ion to be confined in the largest pore spaces, whereas a larger fraction of the porosity is accessible to $\mathrm{Cl}^{-}$. Second, calculations suggest that $\mathrm{Cl}^{-}$has a greater tendency than $\mathrm{Br}^{-}$to form ion pairs and clusters with overall neutral or positive charge that can enter the DDL and possibly even the clay interlayers. Preferential migration of $\mathrm{Cl}^{-}$into the DDL and interlayer water, in the form of ion pairs and clusters, would decrease the $\mathrm{Cl}^{-}: \mathrm{Br}^{-}$ratio in the mobile water.

There is one very broad, but important conclusion that can be drawn from this work. A variety of techniques 
have been developed by research groups to measure the chemical and isotopic composition of porewater in lowpermeability, clay-rich rocks, and there is a tendency to think that these methods should converge on a unique chemical composition. If we accept common conceptual models that suggest porewater in the clay interlayers and in the DDL are cation-rich, and the anions are mostly confined to the mobile water, then it follows that different extraction methods cannot converge on a unique porewater chemical composition unless they happen to extract identical fractions of the interlayer, DDL, and mobile fractions of the porewater. This work demonstrates that the use of multiple extraction methods can lead to an improved understanding of the porewater system.

\section{Conflicts of Interest}

The authors declare that there are no conflicts of interest regarding the publication of this paper.

\section{Acknowledgments}

This research was supported by the Canadian Natural Sciences and Engineering Research Council (NSERC) and the Nuclear Waste Management Organization (NWMO) under Collaborative Research and Development Grant no. CRDPJ 477852 - 14.

\section{References}

[1] S. M. Benson and D. R. Cole, " $\mathrm{CO}_{2}$ sequestration in deep sedimentary formations," Elements, vol. 4, no. 5, pp. 325-331, 2008.

[2] K. S. Lackner, "A guide to CO2 sequestration," Science, vol. 300, no. 5626, pp. 1677-1678, 2003.

[3] J. A. Cherry, W. M. Alley, and B. L. Parker, "Geologic Disposal of Spent Nuclear Fuel," The Bridge on Emerging Issues in Earth Resources Engineering, vol. 44, no. 1, pp. 51-59, 2014.

[4] D. J. Russell and J. E. Gale, "Radioactive waste disposal in the sedimentary rocks of southern Ontario.," Geoscience Canada, vol. 9, no. 4, pp. 200-207, 1982.

[5] M. J. Hendry, D. K. Solomon, M. Person et al., "Can argillaceous formations isolate nuclear waste? Insights from isotopic, noble gas, and geochemical profiles," Geofluids, vol. 15, no. 3, pp. 381386, 2015.

[6] T. A. Al, I. D. Clark, L. Kennell, M. Jensen, and K. G. Raven, "Geochemical evolution and residence time of porewater in low-permeability rocks of the Michigan Basin, Southwest Ontario," Chemical Geology, vol. 404, pp. 1-17, 2015.

[7] F. Bensenouci, J. L. Michelot, J. M. Matray, S. Savoye, J. Tremosa, and S. Gaboreau, "Profiles of chloride and stable isotopes in pore-water obtained from a $2000 \mathrm{~m}$-deep borehole through the Mesozoic sedimentary series in the eastern Paris Basin," Physics and Chemistry of the Earth, vol. 65, pp. 1-10, 2013.

[8] I. D. Clark, T. Al, M. Jensen et al., "Paleozoic-aged brine and authigenic helium preserved in an Ordovician shale aquiclude," Geology, vol. 41, no. 9, pp. 951-954, 2013.

[9] U. Mäder and H. Waber, "Characterization of Pore Water, Ion Transport and Water-rock Interaction in Claystone by Advective Displacement Experiments," Procedia Earth and Planetary Science, vol. 17, pp. 917-920, 2017.
[10] M. Mazurek, P. Alt-Epping, A. Bath et al., "Natural tracer profiles across argillaceous formations," Applied Geochemistry, vol. 26, no. 7, pp. 1035-1064, 2011.

[11] K. Nakata, T. Hasegawa, T. Higashihara, and T. Oyama, "Chloride ion concentrations during the compression of rocks to extract pore water," Geofluids, vol. 16, no. 1, pp. 78-88, 2016.

[12] L. R. Van Loon, P. Wersin, J. M. Soler et al., "In-situ diffusion of HTO, 22Na+, Cs+ and I- in Opalinus Clay at the Mont Terri underground rock laboratory," Radiochimica Acta, vol. 92, no. 9-11, pp. 757-763, 2004.

[13] J. Birkholzer, J. Houseworth, and C.-F. Tsang, "Geologic disposal of high-level radioactive waste: Status, key issues, and trends," Annual Review of Environment and Resources, vol. 37, pp. 79-106, 2012.

[14] M. J. Hendry, S. L. Barbour, B. E. J. Boldt-Leppin, L. J. Reifferscheid, and L. I. Wassenaar, "A comparision of laboratory and field based determinations of molecular diffusion coefficients in a low permeability geologic medium," Environmental Science \& Technology, vol. 43, no. 17, pp. 6730-6736, 2009.

[15] M. J. Hendry and L. I. Wassenaar, "Transport and geochemical controls on the distribution of solutes and stable isotopes in a thick clay-rich till aquitard, Canada," Isotopes in Environmental and Health Studies, vol. 40, no. 1, pp. 3-19, 2004.

[16] M. J. Hendry and L. I. Wassenaar, "Controls on the distribution of major ions in pore waters of a thick surficial aquitard," Water Resources Research, vol. 36, no. 2, pp. 503-513, 2000.

[17] C. E. Neuzil, "Groundwater Flow in Low-Permeability Environments," Water Resources Research, vol. 22, no. 8, pp. 1163-1195, 1986.

[18] D. E. Desaulniers, J. A. Cherry, and P. Fritz, "Origin, age and movement of pore water in argillaceous Quaternary deposits at four sites in southwestern Ontario," Journal of Hydrology, vol. 50, no. C, pp. 231-257, 1981.

[19] T. Gimmi, H. N. Waber, A. Gautschi, and A. Rübel, "Stable water isotopes in pore water of Jurassic argillaceous rocks as tracers for solute transport over large spatial and temporal scales," Water Resources Research, vol. 43, no. 4, Article ID W04410, 2007.

[20] M. J. Hendry, L. I. Wassenaar, and T. Kotzer, "Chloride and chlorine isotopes $(36 \mathrm{Cl}$ and $\delta 37 \mathrm{Cl})$ as tracers of solute migration in a thick, clay-rich aquitard system," Water Resources Research, vol. 36, no. 1, pp. 285-296, 2000.

[21] A. P. Rübel, C. Sonntag, J. Lippmann, F. J. Pearson, and A. Gautschi, "Solute transport in formations of very low permeability: Profiles of stable isotope and dissolved noble gas contents of pore water in the Opalinus Clay, Mont Terri, Switzerland," Geochimica et Cosmochimica Acta, vol. 66, no. 8, pp. 1311-1321, 2002.

[22] M. J. Hendry and G. A. Harrington, "Comparing vertical profiles of natural tracers in the Williston Basin to estimate the onset of deep aquifer activation," Water Resources Research, vol. 50, no. 8, pp. 6496-6506, 2014

[23] G. A. Harrington, W. P. Gardner, B. D. Smerdon, and M. J. Hendry, "Palaeohydrogeological insights from natural tracer profiles in aquitard porewater, Great Artesian Basin, Australia," Water Resources Research, vol. 49, no. 7, pp. 4054-4070, 2013.

[24] C. A. J. Appelo, L. R. Van Loon, and P. Wersin, "Multicomponent diffusion of a suite of tracers ( $\mathrm{HTO}, \mathrm{Cl}, \mathrm{Br}, \mathrm{I}, \mathrm{Na}, \mathrm{Sr}, \mathrm{Cs}$ ) in a single sample of Opalinus Clay," Geochimica et Cosmochimica Acta, vol. 74, no. 4, pp. 1201-1219, 2010. 
[25] H. van Olphen, "Thermodynamics of interlayer adsorption of water in clays. I.-Sodium vermiculite," Journal of Colloid Science, vol. 20, no. 8, pp. 822-837, 1965.

[26] G. Sposito and R. Prost, "Structure of water adsorbed on smectites," Chemical Reviews, vol. 82, no. 6, pp. 553-573, 1982.

[27] D. G. Edwards, A. M. Posner, and J. P. Quirk, "Repulsion of chloride ions by negatively charged clay surfaces: Part 1. Monovalent cation fithian Illites," Transactions of the Faraday Society, vol. 61, pp. 2808-2815, 1965.

[28] P. Wersin, E. Curti, and C. A. J. Appelo, "Modelling bentonitewater interactions at high solid/liquid ratios: Swelling and diffuse double layer effects," Applied Clay Science, vol. 26, no. 1-4, pp. 249-257, 2004.

[29] F. J. Pearson, D. Arcos, A. Bath et al., Mont Terri Project Geochemistry of water in the Opalinus Clay formation at the Mont Terri rock laboratory - Federal Office for the Environment, Federal Office for Water and Geology, Bern, Switzerland, 2003.

[30] Y. Xiang, D. Loomer, and A. Tom, "Improvements in Methodologies for Radiographic Measurement of Diffusion Properties in Low-permeability Rocks, and Development of Methods for $\mathrm{pH}$ Measurement in Brines," NWMO, NWMO-TR-2016-16, 2016.

[31] M. A. McCaffrey, B. Lazar, and Holland, "The evaporation path of seawater and the coprecipitation of $\mathrm{Br}^{-}$and $\mathrm{K}^{+}$with halite," Journal of Sedimentary Petrology, vol. 57, no. 5, pp. 928-937, 1987.

[32] A. A. Chen and R. V. Pappu, "Quantitative characterization of ion pairing and cluster formation in strong 1:1 Electrolytes," The Journal of Physical Chemistry B, vol. 111, no. 23, pp. 6469-6478, 2007.

[33] P. R. Smirnov, "Structural parameters of the nearest surrounding of halide ions in the aqueous electrolyte solutions," Russian Journal of General Chemistry, vol. 83, no. 8, pp. 1469-1481, 2013.

[34] H. Ohtaki and T. Radnai, "Structure and dynamics of hydrated ions," Chemical Reviews, vol. 93, no. 3, pp. 1157-1204, 1993.

[35] M. E. Houben, G. Desbois, and J. L. Urai, "Pore morphology and distribution in the Shaly facies of Opalinus Clay (Mont Terri, Switzerland): Insights from representative 2D BIB-SEM investigations on $\mathrm{mm}$ to $\mathrm{nm}$ scale," Applied Clay Science, vol. 71, pp. 82-97, 2013.

[36] R. Jackson and A. Wigston, "Laboratory petrophysical testing of DGR-3 and DGR-4 core," Intera Engineering, TR-08-28, 2010.

[37] K. Raven et al., "Descriptive Geosphere Site Model," Intera Engineering Ltd. and Nuclear Waste Management Organization, NWMO DGR-TR-2011-24, 2011.

[38] P. Marschall, S. Horseman, and T. Gimmi, "Characterisation of gas transport properties of the Opalinus Clay, a potential host rock formation for radioactive waste disposal," Oil \& Gas Science and Technology - Revue d'IFP Energies nouvelles, vol. 60, no. 1, pp. 121-139, 2005.

[39] F. J. Pearson, "What is the porosity of a mudrock?" Journal of the Geological Society, vol. 158, pp. 9-21, 1999.

[40] L. M. Anovitz and D. R. Cole, "Characterization and analysis of porosity and pore structures," Reviews in Mineralogy and Geochemistry, vol. 80, no. 1, pp. 61-164, 2015.

[41] L. M. Keller, L. Holzer, R. Wepf, and P. Gasser, "3D geometry and topology of pore pathways in Opalinus clay: Implications for mass transport," Applied Clay Science, vol. 52, no. 1-2, pp. 8595, 2011.

[42] H. Gvirtzman and S. M. Gorelick, "Dispersion and advection in unsaturated porous media enhanced by anion exclusion," Nature, vol. 352, no. 6338, pp. 793-795, 1991.
[43] D. Lavoie, C. Rivard, R. Lefebvre et al., "The Utica Shale and gas play in southern Quebec: Geological and hydrogeological syntheses and methodological approaches to groundwater risk evaluation," International Journal of Coal Geology, vol. 126, pp. 77-91, 2014.

[44] M. Koroleva, A. de Haller, U. K. Mader, H. N. Waber, and M. Mazurek, Borehole DGR-2: Pore-water investigations, Institute of Geological Sciences University of Bern, Switzerland, 2008.

[45] A. Skowron and E. Hoffman, "XRD Mineralogical Analysis of DGR-1 and DGR-2 Core," Intera Engineering, TR-08-01, 2009.

[46] C. Yu, J.-M. Matray, J. Gonçalvès et al., "Comparative study of methods to estimate hydraulic parameters in the hydraulically undisturbed Opalinus Clay (Switzerland)," Swiss Journal of Geosciences, vol. 110, no. 1, pp. 85-104, 2017.

[47] S. Sterling, R. Jackson, R. Walsh, D. Heagle, and I. D. Clark, "Assessment of Porosity Data and Gas Phase Presence in DGR Cores," Geofirma Engineering Ltd., TR-08-34, 2011.

[48] M. Mazurek, T. Oyama, P. Wersin, and P. Alt-Epping, "Porewater squeezing from indurated shales," Chemical Geology, vol. 400, pp. 106-121, 2015.

[49] L. R. Van Loon, B. Baeyens, and M. H. Bradbury, "Diffusion and retention of sodium and strontium in Opalinus clay: Comparison of sorption data from diffusion and batch sorption measurements, and geochemical calculations," Applied Geochemistry, vol. 20, no. 12, pp. 2351-2363, 2005.

[50] M. Gascoyne, "Hydrogeochemistry, groundwater ages and sources of salts in a granitic batholith on the Canadian Shield, southeastern Manitoba," Applied Geochemistry, vol. 19, no. 4, pp. 519-560, 2004.

[51] H. N. Waber and J. A. T. Smellie, "Characterisation of pore water in crystalline rocks," Applied Geochemistry, vol. 23, no. 7, pp. 1834-1861, 2008.

[52] F. Bensenouci, J. L. Michelot, J. M. Matray, S. Savoye, M. Massault, and A. Vinsot, "Coupled study of water-stable isotopes and anions in porewater for characterizing aqueous transport through the Mesozoic sedimentary series in the eastern Paris Basin," Marine and Petroleum Geology, vol. 53, pp. 88-101, 2014.

[53] C. Wittebroodt, S. Savoye, P. Jacquier et al., "Comparison between radial diffusion and leaching for determining chloride and sulphate in Tournemire argillite pore water," in presented at the Clays in Natural Barriers for Radioactive Waste Confinement, Lille, France, 2007.

[54] S. Savoye, J.-L. Michelot, C. Wittebroodt, and M. V. Altinier, "Contribution of the diffusive exchange method to the characterization of pore-water in consolidated argillaceous rocks," Journal of Contaminant Hydrology, vol. 86, no. 1-2, pp. 87-104, 2006.

[55] I. C. Yang, Z. E. Peterman, and K. M. Scofield, "Chemical analyses of pore water from boreholes USW SD-6 and USW WT-24, Yucca Mountain, Nevada," Journal of Contaminant Hydrology, vol. 62-63, pp. 361-380, 2003.

[56] A. M. Fernández, D. M. Sánchez-Ledesma, C. Tournassat et al., "Applying the squeezing technique to highly consolidated clayrocks for pore water characterisation: Lessons learned from experiments at the Mont Terri Rock Laboratory," Applied Geochemistry, vol. 49, pp. 2-21, 2014.

[57] A. M. Fernández, A. Bath, H. N. Waber, and T. Oyama, Water sampling by squeezing drillcores, Federal Office for Water and Geology, Bern, Switzerland, 2003.

[58] S. B. Devine, R. E. Ferrel Jr., and G. K. Billings, "The significance of ion exchange to interstitial solutions in clayey sediments," Chemical Geology, vol. 12, no. 3, pp. 219-228, 1973. 
[59] S. Motellier, J. Ly, L. Gorgeon et al., "Modelling of the ionexchange properties and indirect determination of the interstitial water composition of an argillaceous rock. Application to the Callovo-Oxfordian low-water-content formation," Applied Geochemistry, vol. 18, no. 10, pp. 1517-1530, 2003.

[60] A. S. P. Murthy and R. E. Ferrell Jr., "Distribution of major cations in estuarine sediments," Clays and Clay Minerals, vol. 21, no. 3, pp. 161-165, 1973.

[61] M. Celejewski, L. Scott, and T. Al, "An absorption method for extraction and characterization of porewater from lowpermeability rocks using cellulosic sheets," Applied Geochemistry, vol. 49, pp. 22-30, 2014.

[62] E. Sacchi, J.-L. Michelot, H. Pitsch, P. Lalieux, and J.-F. Aranyossy, "Extraction of water and solutes from argillaceous rocks for geochemical characterisation: methods, processes, and current understanding," Hydrogeology Journal, vol. 9, no. 1, pp. 17-33, 2001.

[63] C. A. J. Appelo and D. Postma, Geochemistry, Groundwater and Pollution, CRC Press, 2nd edition, 2005.

[64] P. Wersin, M. Mazurek, U. K. Mäder et al., "Constraining porewater chemistry in a $250 \mathrm{~m}$ thick argillaceous rock sequence," Chemical Geology, vol. 434, pp. 43-61, 2016.

[65] J. M. Azcue and F. Rosa, "Effects of sampling technique on the determination of major ions in sediment pore water," Water Quality Research Journal of Canada, vol. 31, no. 4, pp. 709-724, 1996.

[66] C. A. J. Appelo and P. Wersin, "Multicomponent diffusion modeling in clay systems with application to the diffusion of tritium, iodide, and sodium in opalinus clay," Environmental Science \& Technology, vol. 41, no. 14, pp. 5002-5007, 2007.

[67] Geofirma Engineering Ltd., Geoscientifc characterization of shaft investigation boreholes DGR-7 and DGR-8, NWMO, NWMO DGR-TR-2012-01, 2012.

[68] A. G. Reisdorf, B. Hostettler, D. Jaeggi et al., "Litho- and biostratigraphy of the 250 m-deep Mont Terri BDB-1 borehole through the Opalinus Clay and bounding formations, St Ursanne, Switzerland," Mon Terri Project, Technical report 2016-02, 2016.

[69] A. Borhan and K. K. Rungta, "An Experimental Study of the Radial Penetration of Liquids in Thin Porous Substrates," Journal of Colloid and Interface Science, vol. 158, no. 2, pp. 403411, 1993.

[70] X. Wang, J. A. Hagen, and I. Papautsky, "Paper pump for passive and programmable transport," Biomicrofluidics, vol. 7, no. 1, Article ID 014107, 2013.

[71] D. L. Parkhurst and C. A. J. Appelo, User's guide to PHREEQC (version 2)-A computer program for speciation, batch-reaction, one-dimensional transport, and inverse geochemical calculations: U.S. Geological Survey Water-Resources Investigations, 1999.

[72] A. G. Herrmann, "Bromide distribution between halite and NaCl-saturated seawater," Chemical Geology, vol. 28, no. C, pp. $171-177,1980$.

[73] S. S. D. Foster, "The Chalk groundwater tritium anomaly - A possible explanation," Journal of Hydrology, vol. 25, no. 1-2, pp. 159-165, 1975.

[74] D. L. Sparks, “5 - Sorption Phenomena on Soils," in Environmental Soil Chemistry, pp. 133-186, Academic Press, Burlington, 2nd edition, 2003.

[75] K. T. Hodgson and J. C. Berg, "Dynamic Wettability Properties of Single Wood Pulp Fibers and Their Relationship to Absorbency," Wood and Fiber Science, vol. 20, no. 1, p. 17, 2007.
[76] S. Park, R. A. Venditti, H. Jameel, and J. J. Pawlak, "Changes in pore size distribution during the drying of cellulose fibers as measured by differential scanning calorimetry," Carbohydrate Polymers, vol. 66, no. 1, pp. 97-103, 2006.

[77] C. A. J. Appelo, "Chemistry of water expelled from compacting clay layers: A model based on Donnan equilibrium," Chemical Geology, vol. 19, no. 1-4, pp. 91-98, 1977.

[78] F. S. Barone, R. K. Rowe, and R. M. Quigley, "Laboratory determination of chloride diffusion coefficient in an intact shale," Canadian Geotechnical Journal, vol. 27, no. 2, pp. 177-184, 1990.

[79] C. Tournassat and C. A. J. Appelo, "Modelling approaches for anion-exclusion in compacted Na-bentonite," Geochimica et Cosmochimica Acta, vol. 75, no. 13, pp. 3698-3710, 2011.

[80] C. Tournassat, I. C. Bourg, M. Holmboe, G. Sposito, and C. I. Steefel, "Molecular dynamics simulations of anion exclusion in clay interlayer Nanopores," Clays and Clay Minerals, vol. 64, no. 4, pp. 374-388, 2016.

[81] C. A. J. Appelo, A. Vinsot, S. Mettler, and S. Wechner, "Obtaining the porewater composition of a clay rock by modeling the in- and out-diffusion of anions and cations from an in-situ experiment," Journal of Contaminant Hydrology, vol. 101, no. 1-4, pp. 67-76, 2008.

[82] D. Jougnot, A. Revil, and P. Leroy, "Diffusion of ionic tracers in the Callovo-Oxfordian clay-rock using the Donnan equilibrium model and the formation factor," Geochimica et Cosmochimica Acta, vol. 73, no. 10, pp. 2712-2726, 2009.

[83] L. R. Van Loon, M. A. Glaus, and W. Müller, "Anion exclusion effects in compacted bentonites: towards a better understanding of anion diffusion," Applied Geochemistry, vol. 22, no. 11, pp. 2536-2552, 2007.

[84] M. Descostes, V. Blin, F. Bazer-Bachi et al., "Diffusion of anionic species in Callovo-Oxfordian argillites and Oxfordian limestones (Meuse/Haute-Marne, France)," Applied Geochemistry, vol. 23, no. 4, pp. 655-677, 2008.

[85] Y. Tachi and K. Yotsuji, "Diffusion and sorption of Cs+, Na+, Iand HTO in compacted sodium montmorillonite as a function of porewater salinity: Integrated sorption and diffusion model," Geochimica et Cosmochimica Acta, vol. 132, pp. 75-93, 2014.

[86] P. Grathwohl, Diffusion in Natural Porous Media, Springer, Berlin, 1998.

[87] R. M. Fuoss, "Conductimetric determination of thermodynamic pairing constants for symmetrical electrolytes," Proceedings of the National Acadamy of Sciences of the United States of America, vol. 77, no. 1, pp. 34-38, 1980.

[88] R. M. Fuoss, "Ionic association. III. The equilibrium between ion pairs and free ions," Journal of the American Chemical Society, vol. 80, no. 19, pp. 5059-5061, 1958.

[89] C. A. Kraus, "The ion-pair concept: Its evolution and some applications," The Journal of Physical Chemistry C, vol. 60, no. 2, pp. 129-141, 1956.

[90] Y. Marcus and G. Hefter, "Ion pairing," Chemical Reviews, vol. 106, no. 11, pp. 4585-4621, 2006.

[91] C. J. Fennell, A. Bizjak, V. Vlachy, and K. A. Dill, "Ion pairing in molecular simulations of aqueous alkali halide solutions," The Journal of Physical Chemistry B, vol. 113, no. 19, pp. 6782-6791, 2009.

[92] P. I. Nagy and K. Takács-Novák, “Theoretical and experimental study on ion-pair formation and partitioning of organic salts in octanol/water and dichloromethane/water systems," Journal of the American Chemical Society, vol. 122, no. 28, pp. 6583-6593, 2000 . 
[93] M. Soniat, G. Pool, L. Franklin, and S. W. Rick, "Ion association in aqueous solution," Fluid Phase Equilibria, vol. 407, pp. 31-38, 2015.

[94] W. Wachter, W. Kunz, R. Buchner, and G. Hefter, "Is there an anionic hofmeister effect on water dynamics? Dielectric spectroscopy of aqueous solutions of $\mathrm{NaBr}, \mathrm{NaI}, \mathrm{NaNO} 3$, $\mathrm{NaClO} 4$, and $\mathrm{NaSCN}$," The Journal of Physical Chemistry A, vol. 109, no. 39, pp. 8675-8683, 2005.

[95] S. Altmann, C. Tournassat, F. Goutelard, J.-C. Parneix, T. Gimmi, and N. Maes, "Diffusion-driven transport in clayrock formations," Applied Geochemistry, vol. 27, no. 2, pp. 463-478, 2012.

[96] T. Gimmi, O. X. Leupin, J. Eikenberg et al., "Anisotropic diffusion at the field scale in a 4 -year multi-tracer diffusion and retention experiment - I: Insights from the experimental data," Geochimica et Cosmochimica Acta, vol. 125, pp. 373-393, 2014.

[97] T. P. Wilson and D. T. Long, "Geochemistry and isotope chemistry of Michigan Basin brines: Devonian formations," Applied Geochemistry, vol. 8, no. 1, pp. 81-100, 1993.

[98] T. A. Al, R. Beauheim, R. Crowe et al., "Geosynthesis," NWMO, NWMO DGR-TR-2011-11, 2011.

[99] D. K. Nordstrom and J. L. Munoz, Geochemical Thermodynamics, Wiley, 1994.

[100] C. Wittebroodt, S. Savoye, B. Frasca, P. Gouze, and J.-L. Michelot, "Diffusion of HTO, 36Cl - and 125I - in Upper Toarcian argillite samples from Tournemire: Effects of initial iodide concentration and ionic strength," Applied Geochemistry, vol. 27, no. 7, pp. 1432-1441, 2012. 

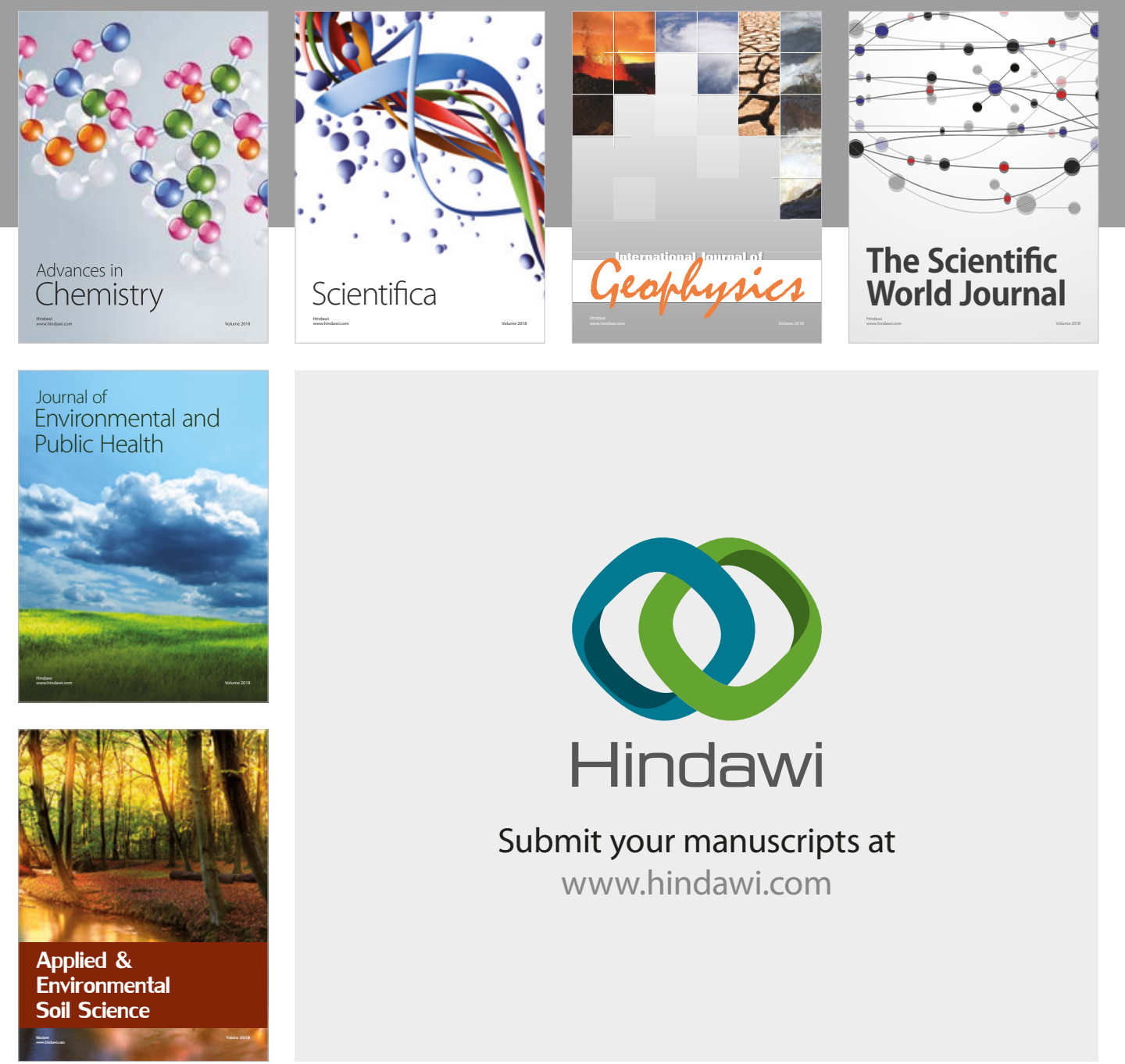

The Scientific

\section{World Journal}
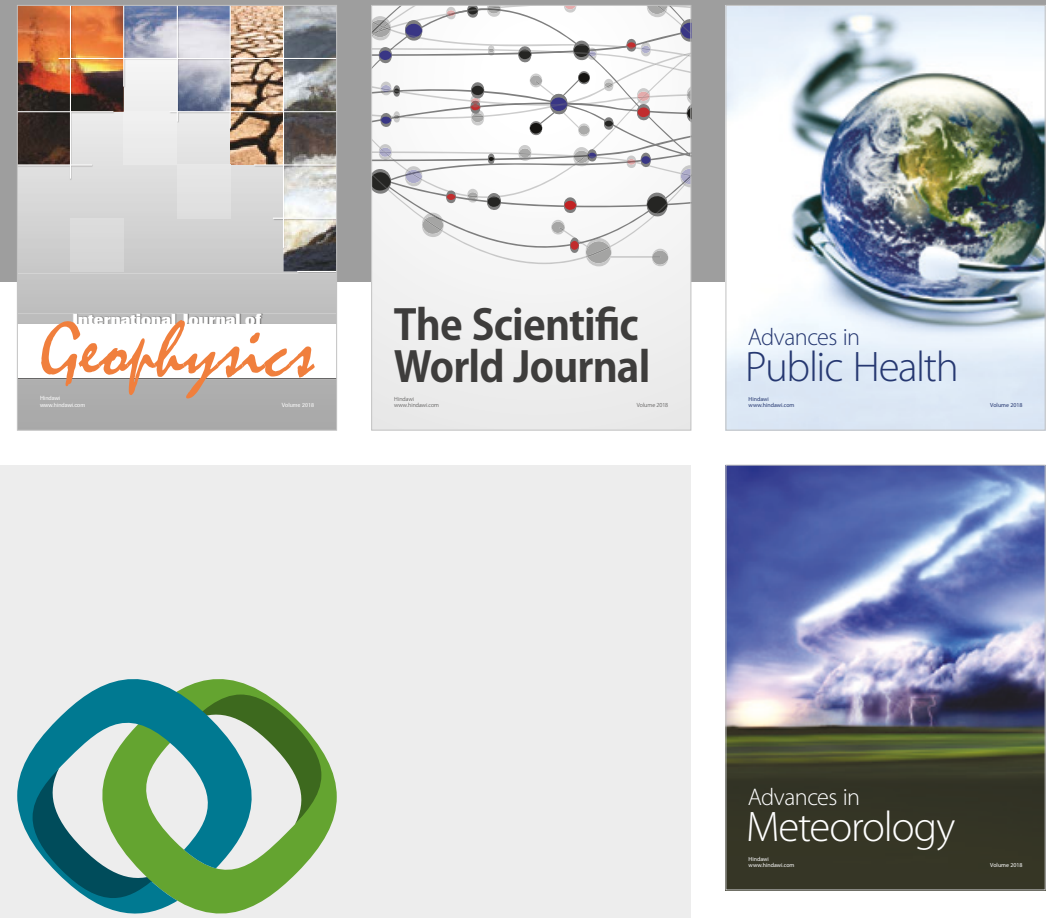

Advan

Public Health

\section{Hindawi}

Submit your manuscripts at

www.hindawi.com
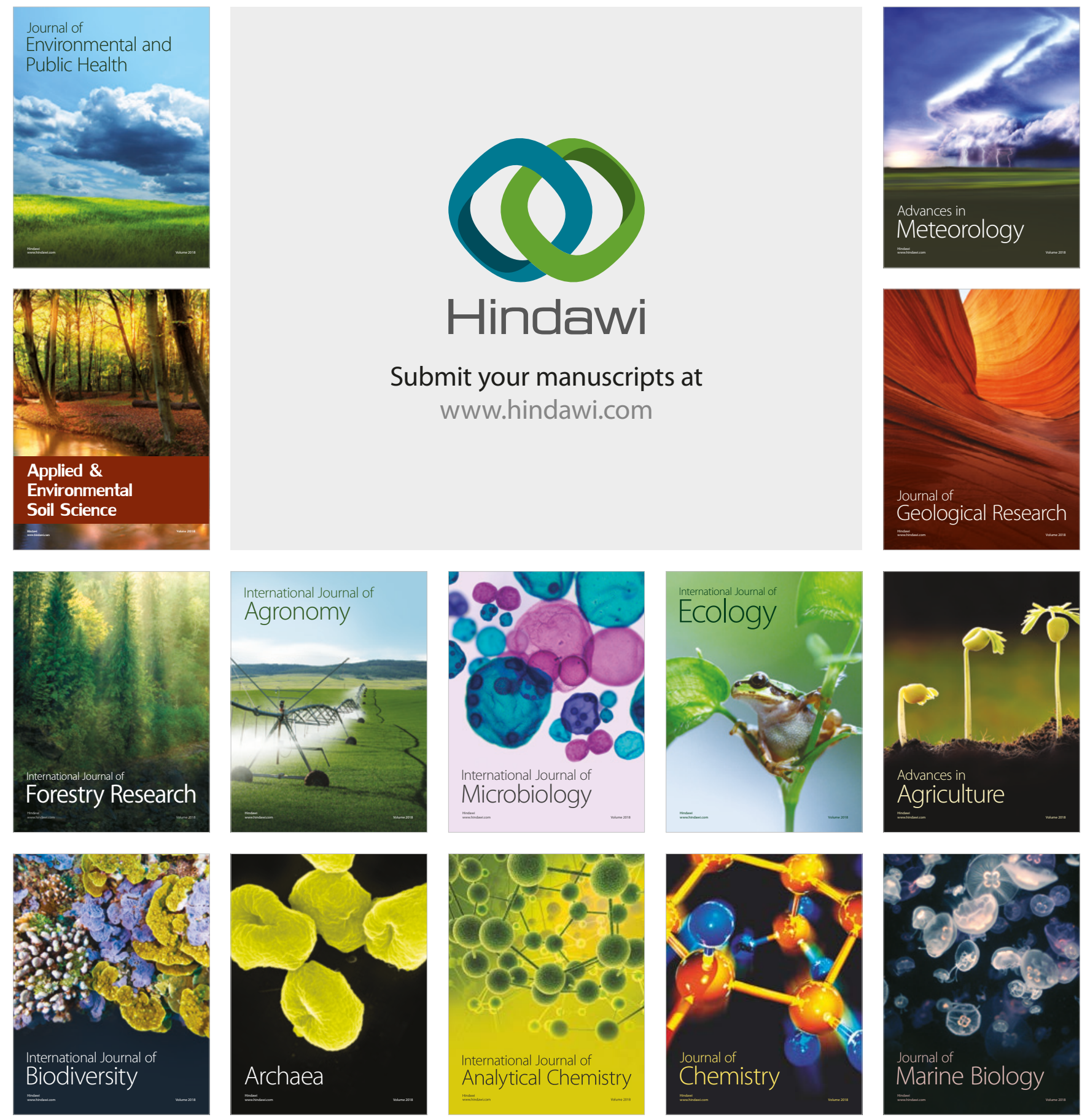